\title{
HOMEGROWN STATELESSNESS IN MALAYSIA AND THE PROMISE OF THE PRINCIPLE OF GENUINE AND EFFECTIVE LINKS
}

\author{
JAMIE CHAI YUN LIEW*
}

\begin{abstract}
Who is stateless and when is a state obligated to confer nationality under international law? Using the case study of Malaysia, this paper sheds light on who are stateless and gives weight to the international customary 'doctrine of dominant and effective nationality' as a factor to consider when conferring citizenship on stateless persons in Malaysia. Six categories of stateless persons were identified in this research project. This article posits that five of the six categories of stateless persons can be said to have 'genuine and effective links' to Malaysia suggesting that not all stateless persons are foreigners or migrants. The research project suggests that in examining who are stateless, different pathways of citizenship should be conceived for them.
\end{abstract}

\section{TABLE OF CONTENTS}

I Introduction 96

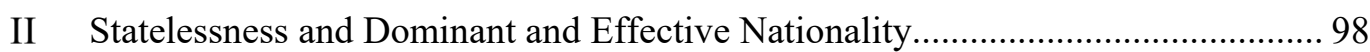

A In Situ Statelessness and the Various Kinds of Statelessness ..................... 98

B International Legal Concept of Dominant and Effective Nationality ......... 99

C The Context of Malaysia: A Thin Human Rights Regime ........................ 101

III Methodology: Interviewing Lawyers, Advocates and Stateless Persons............... 102

IV Relevant Malaysian Citizenship Law .......................................................... 104

V Who Are Stateless in Malaysia? ....................................................................... 107

A Persons with Long-standing Residence Since Pre-Independence and Their Descendants

1 Persons Working in Historical Plantations During Colonial

Times and Their Descendants 108

2 Persons Not Living on Plantations During Colonial Times and Their Descendants.

B People Who Lack Documentation

C Abandoned Children or 'Foundlings' and Adopted Children .... 111

D Children of 'Mixed' Marriages or Alternative Families and Cases Where Children Are Born Out of Wedlock or before a Marriage Was Registered.....

1 Children of Mixed Marriages or Alternative Families 114

Jamie Liew is an Associate Professor at the Faculty of Law, University of Ottawa. This research was supported by the Research Development Grant from the Office of the Vice Dean Research, University of Ottawa and with in-kind support from Lawyers for Liberty and Eric Paulsen, most notably interpretation and research assistance. Special thank you to Nursyahirah Mohd Daud (Syaz) for her invaluable legal research assistance and interpretation on the ground in Malaysia and to Dr Amanda Cheong who at the time was a $\mathrm{PhD}$ candidate (Princeton University) for her collaborative research assistance in identifying persons to talk to, co-conducting interviews and providing information on the Malaysian context. Thank you to all the stateless persons who bravely shared their stories, and the lawyers, civil society representatives and researchers for sharing their valuable time. I hope I have conveyed your stories with respect. I would also like to thank the University of Ottawa Public Law Group for hosting a Works in Progress workshop where I received valuable comments and feedback from colleagues from the Faculties of Law at the University of Ottawa and Queens University. Finally, thank you to the peer reviewers who provided helpful advice on revisions. 
2 Children Born Out of Wedlock or before a Marriage Was

Registered.

E Indigenous Persons

F Refugees and Children of Migrant Workers........

$G$ Intersection of Factors...

VI The Mirage of a Flood: De Facto Citizens in Malaysia .

A The Law of Interpretation - Public Policy is Irrelevant Here

B Majority of Stateless Persons Have Genuine, Effective and

Substantial Links

C There are Built-In Restrictions in the Law for Foreigners

VII Conclusion

VIII Appendix.

\section{INTRODUCTION}

Who is stateless and when is a state obligated to confer nationality under international law? Using the case study of Malaysia, this paper sheds light on who are stateless and gives weight to the international customary doctrine of dominant and effective nationality as a factor to consider when conferring citizenship on stateless persons in Malaysia. This paper shares only part of the results of a larger research project investigating legal barriers and entitlements to citizenship in Malaysia.

This article builds upon existing research in Malaysia on the issue of statelessness. It goes beyond existing research that details how Malaysian law confers citizenship and the promotion of a human rights lens on the issue of statelessness. ${ }^{1}$ This project supports other research that characterises persons as 'being at risk of statelessness', how the invocation of statelessness may 'work against recognition', ${ }^{2}$ and that understanding statelessness requires understanding how it is 'plural and diverse'. ${ }^{3}$

This study is part of a larger research project that provides its findings in two parts. The first is in this paper, focusing on who is stateless in Malaysia. The second provides details on the procedural and substantive legal barriers for stateless persons to obtaining citizenship in Malaysia and will be published elsewhere. This particular article reveals findings from a qualitative survey of case law, lawyers, non-governmental organisations ('NGOs') and stateless

1 See, eg, Raymond Mah and Chloe Lim Yen Hwa, 'Citizenship for Adopted Children - A Malaysian Perspective' (MahWengKwai \& Associates, 10 January 2013) $<$ https://www.mahwengkwai.com/citizenship-for-adopted-children-a-malaysianperspective/>; Choo Chin Low, Report on Citizenship Law: Malaysia and Singapore (GLOBALCIT Country Report No 2017/03, February 2017) $<$ http://cadmus.eui.eu/handle/1814/45371>; Rodziana Mohamed Razali, 'Addressing Statelessness in Malaysia: New Hope and Remaining Challenges' (Working Paper No 2017/9, Institute on Statelessness and Inclusion, 2017); Equal Rights Trust, Confined Spaces: Legal Protections for Rohingya in Bangladesh, Malaysia and Thailand (Report, December 2016) <https://www.equalrightstrust.org/resources/confined-spaces-legalprotections-rohingya-bangladesh-malaysia-and-thailand-0> ('Confined Spaces').

2 Catherine Allerton, 'Contested Statelessness in Sabah, Malaysia: Irregularity and the Politics of Recognition' (2017) 15(3) Journal of Immigrant and Refugee Studies 250; Tenaganita, Acting Today for Tomorrow's Generation: A Report on Regional Conference on Stateless/Undocumented Children in Sabah (Report, 2006) ('Acting for Tomorrow's Generation, Today').

3 Nando Sigona, 'Everyday Statelessness in Italy: Status, Rights, and Camps' (2016) 39(2) Ethnic and Racial Studies 263. 
persons on who is stateless in Malaysia. The survey identifies six categories of stateless persons: (1) persons with long-standing residence since preindependence and their descendants; (2) people who lack documentation; (3) abandoned children or 'foundlings' and adopted children; (4) children of 'mixed' marriages or alternative families and cases where children are born out of wedlock or before a marriage was registered; (5) Indigenous persons; and (6) refugees or children of migrant workers.

In identifying these six categories of stateless persons, this article posits that five of the categories of stateless persons can be said to have 'genuine and effective links' to Malaysia. ${ }^{4}$ In presenting these findings, the paper suggests that not all stateless persons are foreigners or migrants, but are 'homegrown' and within our midst. While there is cogent research suggesting a close association between statelessness and migration, this study proposes that not all statelessness is a consequence of migration. ${ }^{5}$ This research looks at the particular context of in situ statelessness in Malaysia and identifies various incidents of statelessness that do not fit into a singular definition or experience; that they are necessarily foreigners or migrants.

In Malaysia, public discourse often refers to stateless persons as foreign elements. ${ }^{6}$ This paper is a preliminary effort to fill in a gap and support existing research in recognising statelessness in situ and to correct the perception that stateless persons are necessarily foreigners or migrants. ${ }^{7}$ As such, as some early research suggests, statelessness can arise in two different contexts (in situ and migrant), calling for different legal responses. ${ }^{8}$ In doing so, this initial survey suggests that in resolving citizenship cases of the administratively stateless in Malaysia, the international legal concept of dominant and effective nationality can be relied upon.

Part II of this paper explores the legal definition of statelessness and the international customary rule of dominant and effective nationality. Part III

4 The doctrine of 'effective link' was enunciated in Nottebohm (Liechtenstein v Guatemala), in which the International Court of Justice stated that, '[a]ccording to the practice of States, to arbitral and judicial decisions and to the opinion of writers, nationality is a legal bond having as its basis a social fact of attachment, a genuine connection of existence, interests and sentiments, together with the existence of reciprocal rights and duties': Nottebohm (Liechtenstein v Guatemala) (Second Phase) (Judgement) [1955] ICJ Rep 4, 23 ('Nottebohm Case'); See also David Weissbrodt and Clay Collins, 'The Human Rights of Stateless Persons' (2006) 28(1) Human Rights Quarterly 245.

5 See, eg, Rodziana Mohamed Razali, Rohaida Nordin and Tamara Joan Duraisingam, 'Migration and Statelessness: Turning the Spotlight on Malaysia' (2015) 23(S) Pertanika Journal of Social Science and Humanities 19.

6 See, eg, Munguntan Vanar, 'Sabah Seeks to Resolve Issue of Stateless People in the State' The Star (Malaysia, $16 \quad$ November 2018 ) $<$ https://www.thestar.com.my/news/nation/2018/11/16/sabah-seeks-to-resolve-issue-ofstateless-people-in-the-state/>; United Nations High Commissioner for Refugees, 'UNHCR Welcomes Move by Malaysia to Grant Citizenship to Stateless Persons' (15 August 2018) $<$ https://www.unhcr.org/en-my/news/press/2018/8/5b73e54d4/unhcr-welcomes-move-bymalaysia-to-grant-citizenship-to-stateless-persons.html $>$.

7 See generally Tendayi Bloom, Katherine Tonkiss and Phillip Cole (eds), Understanding Statelessness (Routledge 2017); Mely Caballero-Anthony, Priyanka Bhalla and Pau Khan Khup Hangzo, 'The Many Faces of Statelessness' (Report, NTS Alert, February 2010) $<$ http://www.rsis.edu.sg/wpcontent/uploads/2014/07/NL100228_NTS_Alert_Feb2010_Issue2.pdf $>$ : where the report discusses stateless persons in their habitual residence.

8 Caia Vlieks, "Contexts of Statelessness: The Concepts "Statelessness In Situ" and "Statelessness in the Migratory Context"' in Tendayi Bloom, Katherine Tonkiss and Phillip Cole (eds), Understanding Statelessness (Routledge, 2017) 35. 
presents the methodology of the research undertaken to identify stateless persons in Malaysia. Part IV focuses on Malaysian nationality law. Part V presents the findings of the research.

While this paper does the preliminary work of identifying who is stateless, it does not present potential legal routes to citizenship for each category and/or how the different pathways may be applied differently to different categories of stateless persons in Malaysia. That is beyond the scope of this paper and I invite other scholars and advocates to provide this work.

\section{Statelessness AND Dominant AND EFFECTIVE NATIONALITY}

\section{A In Situ Statelessness and the Various Kinds of Statelessness}

Scholars have described statelessness as occurring in two different contexts: in the migratory context and statelessness in situ. ${ }^{9}$ As Gábor Gyulai states, in situ stateless persons include, "[p]ersons [who] are in their "own country", meaning a country with which they have significant and stable ties (through birth, long-term residence, etc.)'. ${ }^{10}$ This article is not preoccupied with creating an exhaustive list of factors that would be used to determine what constitutes stable ties or genuine and effective links. However, the article considers birth, long-term residence and birth to a parent with citizenship as important factors that do suggest genuine and effective links with a country.

In this research project, I use a few terms to refer to persons stateless in situ. First, I refer to a stateless person and de facto stateless synonymously as a person who is either stateless and is a migrant or a stateless person in situ; persons who have no legal recognition as a citizen in any state. Second, I refer to three terms, de jure stateless, 'administratively' stateless persons and de facto citizens, synonymously as persons who have no legal recognition as a citizen in any state but may have legal entitlement to citizenship; that is persons who are entitled on the face of the law but due to various administrative or legal barriers, are unable to obtain the legal proof of citizenship. Some scholars may question my use of the term 'stateless' for persons who appear to meet the legal requirements for citizenship and prefer to use the term 'undocumented citizen'. My view, informed from this wider research project of legal barriers to obtain citizenship, is that the legal fact of being conferred citizenship is important. As such, persons should be considered stateless until they are legally recognised as a citizen. This

9 See generally, Kristy Belton, Statelessness in the Caribbean: The Paradox of Belonging in a Postnational World (University of Pennsylvania Press 2018); Gábor Gyulai, 'Statelessness in the EU Framework for International Protection' (2012) 14(3) European Journal of Migration and Law 279; Mark Manly, 'UNHCR's Mandate and Activities to Address Statelessness in Europe' (2012) 14(3) European Journal of Migration and Law 261; Laura Van Waas and Monica Neal, 'Statelessness and the Role of National Human Rights Institutions' (Legal Studies Research Paper Series No 022/2013, Tilburg Law School, October 2013).

10 Gyulai (n 9) 279. See also United Nations High Commissioner for Refugees, 'Expert Meeting - Statelessness Determination Procedures and the Status of Stateless Persons' (Summary Conclusions, 7 December 2010) 6 [24]. 
is confirmed in the definition outlined in the 1954 Convention Relating to the Status of Stateless Persons ('1954 Statelessness Convention'). ${ }^{11}$

Third, I refer to refugees as persons who self-identify or have been identified by NGOs/advocates (including the United Nations High Commissioner for Refugees ('UNHCR')) as persons who are fleeing persecution, as outlined in the Convention Relating to the Status of Refugees ('Refugee Convention'), 12 and persons who are fleeing torture and unusual and undeserved treatment, as outlined in the Convention against Torture and Other Cruel, Inhuman or Degrading Treatment or Punishment ('Convention against Torture'). ${ }^{13}$ I refer to migrants as persons who have themselves moved to Malaysia, which may or may not include their children. If the migrant person's child was born in Malaysia, I do not consider the child a migrant. Finally, Indigenous persons refers to any person in Malaysia that self-identifies as belonging to the Orang Asli, Orang Ulu and the Anak Negeri peoples, ethnic minorities. While people of Malay descent are also indigenous to Malaysia, they constitute the majority of the population and are politically, economically and socially dominant and therefore are not ethnic minorities. ${ }^{14}$

\section{B International Legal Concept of Dominant and Effective Nationality}

The legal definition of statelessness is generally understood in a singular manner as encompassing a homogenous group of people who share one characteristic: they do not have citizenship whatsoever. Indeed, as the 1954 Statelessness Convention states, "For the purpose of this Convention, the term "stateless person" means a person who is not considered as a national by any State under the operation of its law'. ${ }^{15}$ As Carol Batchelor writes:

This [definition] is concise and to the point. It defines a specific group of people, the de jure stateless, because it delineates a specific, quantifiable fact: either one is, or one is not a national by operation of a State's law... the definition itself precludes full realization of an effective nationality because it is a technical, legal definition which can address only technical, legal problems. ${ }^{16}$

The UNHCR Handbook on the Protection of Stateless Persons tries to resolve the conflict presented when the law appears to confer citizenship but the state implements the law in a differential manner:

Where the competent authorities treat an individual as a non-national even though he or she would appear to meet the criteria for automatic acquisition of nationality under the operation of a country's laws, it is their position rather than the letter of

11 Convention Relating to the Status of Stateless Persons, opened for signature 28 September 1954, 360 UNTS 117 (entered into force 6 June 1960) art 1 ('1954 Statelessness Convention').

12 Convention Relating to the Status of Refugees, opened for signature 28 July 1951, 189 UNTS 137 (entered into force 22 April 1954) art 1(A)(2) ('Refugee Convention').

13 Convention against Torture and Other Cruel, Inhuman or Degrading Treatment or Punishment, opened for signature 10 December 1984, 1465 UNTS 85 (entered into force 26 June 1987) ('Convention against Torture').

14 Department of Statistics Malaysia, 'Population Distribution and Basic Demographic Characteristic Report 2010' (Census Report, 5 August 2011) $<$ https://www.dosm.gov.my/v1/index.php? $\mathrm{r}=$ column/ctheme\&menu id=L0pheU43NWJwR WVSZklWdzQ4TlhUUT09\&bul_id=MDMxdHZjWTk1SjFzTzNkRXYzcVZjdz09>.

151954 Statelessness Convention (n 11) art 1.1.

16 Carol A Batchelor, 'Stateless Persons: Some Gaps in International Protection' (1995) 7(2) International Journal of Refugee Law 232, 232. 
the law that is determinative in concluding that a State does not consider such an individual as a national. 17

Thus, as Paul Weis points out, stateless persons are 'amorphous' as there are various ways in which a person can become stateless whether by operation of the law or by state action or inaction as it may be. ${ }^{18}$ While early drafters of the 1954 Statelessness Convention and Convention on the Reduction of Statelessness ('1961 Statelessness Convention') ${ }^{19}$ were preoccupied with whether to include de facto stateless in the definition of statelessness, ultimately, the Conventions focuse on those that are de jure stateless.

Despite this rigid definition in the conventions, scholars have started pointing to emerging norms of international law that appear to increase a state's obligation to confer nationality, including the right to nationality as espoused in various international conventions. ${ }^{20}$ Peter Spiro writes:

[I]t is becoming increasingly clear that state discretion is no longer unfettered and that citizenship practice must account for the interests of individuals as well as those of states... The new law of citizenship, by contrast, may dictate citizenship eligibility for habitual residents and their children, with implications for the character of national community... [E]merging norms point to limitations on threshold naturalization requirements for long-term residents, and the trajectory suggests a move toward the required adoption, at least in some contexts, of a jus soli basis for birthright citizenship... The prospective norm holds that habitual residents and their progeny should not be relegated to noncitizen status indefinitely and that at some point in time, territorial presence should give rise to baseline eligibility for citizenship acquisition. ${ }^{21}$

Thus, Spiro notes, Nottebohm (Liechtenstein v Guatemala) ("Nottebohm Case') 'may supply a sort of inverse conceptual guide to the future international law of citizenship'. ${ }^{22}$ International law scholars will remember the Nottebohm Case, which involved a claim by Liechtenstein against Guatemala for the wrongful seizure without compensation of the property of a Liechtenstein national. ${ }^{23}$ Friedrich Nottebohm (born 1881) was German national by birth but

17 United Nations High Commissioner for Refugees, Handbook on Protection of Stateless Persons under the 1954 Convention Relating to the Status of Stateless Persons (United Nations High Commissioner for Refugees 2014) 16 [37].

18 Paul Weis, 'The Convention Relating to the Status of Stateless Persons' (1961) 10(2) International and Comparative Law Quarterly 255, 263.

19 Opened for signature 30 August 1961, 989 UNTS 175 (entered into force 13 December 1975) ('1961 Statelessness Convention').

20 International Covenant on Civil and Political Rights, opened for signature 19 December 1966, 999 UNTS 171 (entered into force 23 March 1976) art 24(3) ('ICCPR'); Convention on the Rights of the Child, opened for signature 20 November 1989, 1577 UNTS 3 (entered into force 2 September 1990) arts 7(1)-(2) ('CRC'); Convention on the Elimination of All Forms of Discrimination against Women, opened for signature 18 December 1979, 1249 UNTS 13 (entered into force 3 September 1981) art 9(1); International Convention on the Elimination of All Forms of Racial Discrimination, opened for signature 7 Mar 1966, 660 UNTS 195 (entered into force 4 January 1969) art 1(3) ('CERD'); Universal Declaration of Human Rights, GA Res 217A (III), UN GAOR, UN Doc A/810 (10 December 1948) art 15 ('UDHR').

21 Peter J Spiro, 'A New International Law of Citizenship' (2011) 105(4) American Journal of International Law 694, 717, 718, 720. See also Case of the Yean and Bosico Children v The Dominican Republic (Judgment) (Inter-American Court of Human Rights, Series C 130, 8 September 2005) 58 [140].

22 Spiro (n 21) 722.

23 Nottebohm Case (n 4) 13. 
became a citizen of Liechtenstein in 1939. ${ }^{24}$ Nottebohm was, however, a longterm resident of Guatemala and had few ties to Liechtenstein. ${ }^{25}$ Guatemala challenged the admissibility of Liechtenstein's claim on the ground that Nottebohm's naturalisation to Liechtenstein was defective. ${ }^{26}$ The International Court of Justice ('ICJ') agreed with Nottebohm and Guatemala, peering behind the veil of naturalisation to find that his citizenship with Liechtenstein was not 'real and effective'. ${ }^{27}$ The ICJ noted, 'nationality is a legal bond having as its basis a social fact of attachment, a genuine connection of existence, interests and sentiments, together with the existence of reciprocal rights and duties' ${ }^{28}$

Since the Nottebohm Case, there have been a series of international law cases dealing with dual nationals that have adopted this 'dominant and effective' test espousing the examination of relevant factors such as 'habitual residence, center of interests, family ties, participation in public life and other evidence of attachment'. ${ }^{29}$ As Charles Brower and Jason Brueschke suggest, the increasing number of cases in which tribunals have turned to the dominant and effective nationality test (albeit in the context of dual nationals) 'certainly represent a large source of precedent on the subject, which should serve as useful examples in other contexts'. 30 The Nottebohm Case

is seen as authority for the position that there should be an 'effective' or 'genuine' link between the individual and the State of nationality, not only in the case of dual or plural nationality (where such a requirement is generally accepted), but also where the national possesses only one nationality. ${ }^{31}$

\section{The Context of Malaysia: A Thin Human Rights Regime}

Malaysia is a signatory to the Universal Declaration of Human Rights ${ }^{32}$ and the Convention on the Rights of the Child, both of which provide rights to citizenship. ${ }^{33}$ However, Malaysia is not a party to the 1954 Statelessness Convention or the 1961 Statelessness Convention, ${ }^{34}$ the Refugee Convention, ${ }^{35}$ the International Convention on the Elimination of All Forms of Racial Discrimination, ${ }^{36}$ the International Covenant on Civil and Political Rights ('ICCPR'), ${ }^{37}$ the Convention against Torture; ${ }^{38}$ among others. In response to

24 ibid.

25 ibid.

26 ibid 16 .

27 ibid 22-25.

28 ibid 23 .

29 Case No A/18 (1984) 75 ILR 176, 173 [5] (Iran-United States Claims Tribunal); 'Claims of Dual Nationals in the Modern Era: The Iran-United States Claims Tribunal' (1984) 83(3) Michigan Law Review 597, 601; Abraham Kannoff, 'Dueling Nationalities: Dual Citizenship, Dominant and Effective Nationality, and the Case of Anwar Al-Aulaqi' (2011) 25(3) Emory Law Review 1372, 1390-1.

30 Charles N Brower and Jason D Brueschke, The Iran-United States Claims Tribunal (Martinus Nijhoff 1998) 321.

31 John R Dugard, Special Rapporteur, First Report on Diplomatic Protection, UN Doc, A/CN.4/506 (7 March 2000 and 20 April 2000) 228 [106].

$32 \operatorname{UDHR}(\mathrm{n} 20)$.

$33 \quad C R C$ (n 20).

341954 Statelessness Convention (n 11); 1961 Statelessness Convention (n 19).

35 Refugee Convention (n 12).

36 CERD (n 20).

$37 \operatorname{ICCPR}(\mathrm{n} 20)$. 
calls to sign and ratify some of these conventions, Malaysia has cited it is not ready and still in consultation to ensure its preparedness to join as a signatory. Recently, Senator P Waytha Moorthy, Minister in the Prime Minister's Department, has said that the Human Rights Commission of Malaysia (Suhakam) wants Malaysia to ratify these six United Nations treaties pertaining to human rights. ${ }^{39}$ Still, there has been no indication that the State of Malaysia will follow this recommendation.

As Malaysia is not a signatory to many of the major international conventions related to human rights, there has been very little use of human rights language in domestic statelessness cases. Some advocates, who were interviewed, mentioned that the turn to human rights sometimes harmed a legal case involving a stateless person. ${ }^{40}$ As the full menu of human rights instruments are not available and the use of human rights provisions or mechanisms have been met with hostility in some legal venues, the language of rights is not always a viable tool for stateless persons in Malaysia. With this in mind, this article focuses on what other factors could persuade the state to confer citizenship on different categories of stateless persons. In legal parlance, and in my discussions with advocates and stateless persons alike, a common argument made was that many stateless persons were de facto citizens in every sense of the word, except in the legal sense. This article suggests that the international legal concept of a 'genuine and effective link' could and should be deployed to convince states they have an obligation to confer citizenship on various categories of stateless persons in Malaysia. This research paper invites scholars and advocates alike to point to the 'dominant and effective nationality' test to be used in not only the dual nationality context but also the statelessness context.

\section{Methodology: INTERVIEWING LAWYERS, AdVOCATES AND STATELESS}

\section{PERSONS}

The larger research project on which this paper is based engaged with the reported cases of stateless persons seeking citizenship and also involved oral interviews with experts, service providers and stateless persons themselves. The main reason why interviews were conducted is because many cases of statelessness are unreported and those that are reported, do not contain all the information I sought for this research project. Between 1 January 2018 and 26 April 2018, 44 people were interviewed in Malaysia for this project. I conducted unstructured interviews with 8 lawyers, two paralegals, 13 NGO representatives, three academics (including one $\mathrm{PhD}$ student), as well as 18 stateless persons. As well, in February 2018, I attended and observed a registration rally organised by an opposition political party that brought 40 stateless persons to a registration centre to help them submit applications for citizenship.

This research was conducted in partnership with an NGO called Lawyers for Liberty in Malaysia, an organisation that has been involved in litigating cases for stateless persons and advocating for greater access to citizenship for stateless

38 Convention against Torture (n 15).

39 'Suhakam Wants Malaysia to Ratify Six Human Rights Conventions, Says Waytha Moorthy' The Star (Putrajaya, 21 August 2018) $<$ https://www.thestar.com.my/news/nation/2018/08/21/suhakam-wants-malaysia-to-ratifysix-human-rights-conventions/>.

40 See Appendix Table 3, 5L. 
persons in Malaysia. A potential list of persons to interview was developed by mining current case law of lawyers who work on cases involving stateless persons, doing an internet search of NGOs that service and advocate for and on behalf of stateless persons, and discussing with Lawyers for Liberty and a fellow researcher ( $\mathrm{PhD}$ candidate conducting sociological research on stateless persons) who would be ideal participants.

I came into contact with interview participants by making cold call introductions via e-mail or WhatsApp (a social media app). Introductions to me and my research project were also made by Lawyers for Liberty by e-mail or WhatsApp. Some of the interviewees, after speaking with them, then directed me to contact other persons that they thought would be able to provide useful information for the study (resulting in a snowball effect) including identification of stateless persons. A few stateless persons contacted Lawyers for Liberty on their own volition after they discovered the study was being undertaken, wanting their voices to be heard. Interviews were conducted in several locations in Malaysia: Kuala Lumpur, Kuala Selangor, Klang, Penang, Miri and Kota Kinabalu, covering both West (peninsular) and East Malaysia (Borneo island). As some interviewees did not speak English, a research assistant with Lawyers for Liberty accompanied me to provide legal and linguistic translation. In a few instances, I was able to communicate with persons using Hokkien (Chinese).

Many of the interviewees who are not stateless persons have extensive experience working with stateless persons. ${ }^{41}$ Others conducted research on the issue of statelessness or provided advocacy and lobbying support. ${ }^{42}$

The study has anonymised the names of the interviewees to protect the identities of the stateless persons that are referred to in the stories and information shared with this research project. Lawyers and NGOs were also anonymised as their identification could lead to the identification of a particular stateless person or case. Many stateless persons interviewed have pending cases and this research does not wish to interfere with their chances of success. Consequently, an anonymised identification code was assigned to each interviewee (a number and an alphabetical code: L for lawyers; NGO for NGOs; PL for paralegal; A for academic; $\mathrm{S}$ for stateless person; $\mathrm{PhD}$ for $\mathrm{PhD}$ candidate) and will be used to cite the interviewees in this work.

In all, 18 stateless persons discussed their personal cases with me, the paralegals discussed 2 cases, the lawyers 20 cases, the NGOs 16 cases and the academics 4 cases totalling 60 cases of statelessness documented in this paper.

This study acknowledges that more stateless persons and NGO representatives could have been interviewed. However, the study's initial findings still provide an important picture of how statelessness is conceived in

41 One paralegal explained he had helped approximately 50 persons within a nine-year period to obtain citizenship and that in his estimation, only 20 percent successfully obtained citizenship: Appendix Table 3, Interview with 1PL. Another NGO representative said she had personally helped over 100 children and only two people had obtained citizenship successfully: Appendix Table 3, Interview with 10NGO. One lawyer discussed taking 10 cases through the courts within a ten-year period with mixed success rates: Appendix Table 3, Interview with 5L.

42 The $\mathrm{PhD}$ student interviewed conducted over 100 interviews of stateless persons, mainly in the state of Sabah: Appendix Table 3, Interview with 1PHD. One NGO interviewee explained that they did not meet with stateless persons personally but work with organisations that do and also engaged in lobbying and advocating for stateless persons with the government: Appendix Table 3, Interview with 6NGO. 
Malaysia. This study encourages further and deeper research on mapping out who is stateless in Malaysia and the lived experiences of those persons.

\section{ReleVAnt Malaysian Citizenship LAW}

In order to understand how statelessness is created, one must briefly examine the relevant aspects of Malaysia's citizenship law. This paper does not aim to present a comprehensive overview of how one obtains citizenship as other scholars have done this work. ${ }^{43}$ It is also important to understand that while the below discusses citizenship law within the framework of the Federal Constitution of Malaysia ('Federal Constitution'), other pieces of legislation are important to understand, including the 1952 Adoption Act 44 and the 1961 Legitimacy Act. ${ }^{45}$ Examining the full scope of these pieces of legislation is beyond the scope of this paper. As well, as indicated above, this article is a piece of a wider research project examining the legal barriers to citizenship. The mapping of, and examination of, the legal barriers to citizenship is provided in other writing. ${ }^{46}$

There are essentially four different ways a person can acquire citizenship in Malaysia: by operation of law or automatically; ${ }^{47}$ by registration; ${ }^{48}$ by naturalisation; ${ }^{49}$ or by incorporation of territory. ${ }^{50}$ Citizenship by operation of law (automatic) is enunciated in art 14 of the Federal Constitution, as such:

(1) Subject to the provisions of this Part, the following persons are citizens by operation of law, that is to say:

(a) every person born before Malaysia Day who is a citizen of the Federation by virtue of the provisions contained in Part I of the Second Schedule; and

(b) every person born on or after Malaysia Day, and having any of the qualifications specified in Part II of the Second Schedule.

This provision should be read with pt II of sch II, s 1:

(a) Subject to the provisions of Part III of this Constitution, the following persons born on or after Malaysia Day are citizens by operation of law, that is to say:

43 See, eg, Allerton, 'Contested Statelessness in Sabah' (n 2); Acting for Tomorrow's Generation, Today (n 2). This paper also does not provide an overview of the rules of state succession, which may provide an explanation of how some people may not have acquired citizenship when Malaysia became independent. As I allude to above, even if state succession rules did confer citizenship, some simply did not obtain citizenship due to administrative and other legal barriers, which are discussed in other writing from this research project.

44 Adoption Act 1952 (Malaysia).

45 Legitimacy Act 1961 (Malaysia, $1971 \mathrm{rev}$ ed).

46 See, eg, Development of Human Resources for Rural Areas Malaysia, 'Awareness Handbook: Understanding Statelessness in Malaysia' (Handbook, 31 January 2019) $<$ http://dhrramalaysia.org.my/handbooks-on-statelessness-by-dhrra-malaysia/>;

Development of Human Resources for Rural Areas Malaysia, 'Mapping \& Registration Project Fact Sheet' (Fact Sheet, August 2014) <http://dhrramalaysia.org.my/wpcontent/uploads/2014/09/Fact-Sheet-on-Mapping-and-Registration-August-2014-DHRRAMalaysia.pdf $>$.

47 Federal Constitution (Malaysia) art 14.

48 ibid arts 15-18.

49 ibid art 19.

50 ibid art 22. 
(b) every person born within the Federation of whose parents one at least is at the time of the birth either a citizen or permanently resident in the Federation; and

(c) every person born outside the Federation whose father is at the time of the birth a citizen and either was born in the Federation or is at the time of the birth in the service of the Federation or of a State; and

(d) every person born outside the Federation whose father is at the time of the birth a citizen and whose birth is, within one year of its occurrence or within such longer period as the Federal Government may in any particular case allow, registered at a consulate of the Federation or, if it occurs in Brunei or in a territory prescribed for this purpose by order of the Yang di-Pertuan Agong, registered with the Federal Government; and

(e) every person born in Singapore of whose parents one at least is at the time of the birth a citizen and who is not born a citizen otherwise than by virtue of this paragraph; and

(f) every person born within the Federation who is not born a citizen of any country otherwise than by virtue of this paragraph. ${ }^{51}$

On the face of the Federal Constitution, every stateless person born within Malaysia is entitled to citizenship automatically. Having a parent who is a Malaysian citizen or permanent resident also entitles one to Malaysian citizenship automatically. ${ }^{52}$ Relying on a parental link is complicated, as art 14 should also be read with pt II s 17 in sch II, which states:

For the purposes of Part III of this Constitution references to a person's father or to his parent, or to one of his parents, are in relation to a person who is illegitimate to be construed as references to his mother, and accordingly section 19 of this Schedule shall not apply to such a person. ${ }^{53}$

This provision has been interpreted to mean that where a person's parents are not legally married, a child's citizenship follows the mother's citizenship and not the father's. ${ }^{54}$ Thus, where a child is considered 'illegitimate', the child cannot benefit from acquiring citizenship from her father, even if he is her only Malaysian parent. This provision is irrelevant, however, if the stateless person was born in Malaysia; it is not necessary to have a Malaysian parent. The Federal Constitution under art 14(1)(b), pt II s 1(e) in sch II provides a safety net for statelessness by providing that every person born within Malaysia, "who is not born a citizen of any country otherwise', is also a citizen. ${ }^{55}$ This provision should be read with sch II pt II s 2(3):

For the purposes of paragraph (e) of section 1 a person is to be treated as having at birth any citizenship which he acquires within one year afterwards by virtue of any provision corresponding to paragraph (c) of that section or otherwise. ${ }^{56}$

\footnotetext{
51 ibid sch II pt II s 1; art 14(1)(b).

52 ibid sch II pt II s 1(a).

53 ibid art 17; ibid sch II pt II s 1(a).

54 See, eg, Yu Sheng Meng (A Child Represented by His Litigator, Yu Meng Queng) v Ketua Pengarah Pendaftaran Negara \& Ors [2016] 7 MLJ 628 (Asmabi Mohamad J) (High Court of Malaya).

55 Federal Constitution (Malaysia) art 14(1)(b); ibid sch II pt II s 1(a).

56 ibid sch II pt II s 2(3).
} 
Subsection 2(3) then provides an interpretive guide for $\mathrm{s} 1(\mathrm{e})$ in that a person 'who is not born a citizen of any country otherwise' includes persons, born in Malaysia, who have not acquired citizenship within one year after their birth. The failsafe provision, however, has not been interpreted in this way. The Malaysian Government has interpreted the words, "who is not born a citizen of any country otherwise' as a requirement to assess whether a stateless person has explored obtaining alternative citizenship, especially where one parent is suspected or known to be a foreigner. ${ }^{57}$ Some interpret the provision as not including the requirement to look for a parental or blood link and the plain language meaning and interpretation of these provisions certainly appear not to call for such a link. ${ }^{58}$

Registration (as opposed to an application for citizenship) also provides a means to acquire citizenship. Registration, however, is not a means to obtain citizenship automatically (by operation of law). Certain requirements must be met as well as a positive discretion on the part of the Minister of Home Affairs or his delegate. While there are several provisions detailing the requirements, of note is art 15A of the Federal Constitution. This provision is sometimes seen as another failsafe mechanism for children who may not otherwise qualify for citizenship. It provides:

Subject to Article 18, the Federal Government may, in such special circumstances as it thinks fit, cause any person under the age of twenty-one years to be registered a citizen. 59

Article 15A provides wide discretionary powers to the Minister of Home Affairs to grant citizenship to anyone less than 21 years old. While this may seem like a viable method to apply for citizenship, a decision made via art 15(A) is only applicable to children, is at the whim of the Minister and is not as powerful as gaining citizenship by operation of law (where one is entitled and is automatically conferred citizenship). Article 15(A) provides precarious citizenship, however, as it is subject to revocation.

With this brief overview of the citizenship framework, the next section discusses how, under these laws, persons may be rendered administratively stateless.

57 See, eg, Than Siew Beng \& Anor v Ketua Pengarah Jabatan Pendaftaran Negara \& Ors [2015] MLJU 2059 (Unreported, High Court of Malaya, Asmabi Mohamad J, 16 November 2015) 10-13; Than Siew Beng \& Anor v Ketua Pengarah Jabatan Pendaftaran Negara \& Ors [2017] 5 MLJ 662 (David Wong, Badariah Sahamid and Harmindar Singh JJCA) (Court of Appeal);

58 See, eg, Appendix Table 2, Interview with 5L.

59 Federal Constitution (Malaysia) art 15(A). 


\section{Who ARE StATELESS IN MALAYSIA?}

The following sections identify six groups of persons in Malaysia that are stateless. ${ }^{60}$ Five of the six groups can be considered to be administratively stateless persons, while the last group would include genuine stateless persons.

In categorising stateless persons in this way, the article does not provide nuanced legal opinion as to stateless persons eligibility or entitlement to citizenship. Nevertheless, in many of the cases, on the face of the law in Malaysia, persons identified in five of the categories appear to meet the legal requirements for citizenship but face administrative or legal barriers from obtaining citizenship. These barriers as well as the potential reasons why people remain stateless are discussed in further writing and are outside the scope of this paper.

The difference between the five groups and the last group is the existence (among the five groups) of a genuine and effective link to the state by birth, long-standing residence in the state and/or a parent who has Malaysian citizenship. In some instances, however, the sixth group may also contain cases of stateless persons who also have an effective and genuine link to Malaysia. The table in the appendix sets out the types of stateless cases that were identified in this study and what follows is a discussion of each category. ${ }^{61}$

\section{A Persons with Long-standing Residence Since Pre-Independence and Their}

\section{Descendants}

This category involves persons who have been living in Malaysia prior to Malaysia gaining independence on 31 August 1957 (Merdeka Day) and forming a federation on 16 September 1963 (Malaysia Day). Subsection 14(1) of the Federal Constitution explicitly provides that every person born before Malaysia Day who was a citizen of the Federation are automatically citizens. ${ }^{62}$ As well, ss 16 and 16A of the Federal Constitution provide, in general, citizenship by registration to persons who were born in Malaysia before Merdeka Day where they can show they have resided in Malaysia seven years preceding the date of application, they intend to reside permanently in Malaysia, '[are] of good

60 It is important to note that there are various reasons why the six groups of stateless persons in Malaysia find themselves stateless; there are political, economic, social and other factors that inform the vulnerability of this population. This is outside the scope of this paper but a brief overview of why stateless persons are vulnerable is found in other writing. See, eg, Catherine Allerton, 'Statelessness and the Lives of the Children of Migrants in Sabah, East Malaysia' (2014) 19(1-2) Tilburg Law Review 26; Avyanthi Azis, 'Urban Refugees in a Graduated Sovereignty: The Experiences of the Stateless Rohingya in the Klang Valley' (2014) 18(8) Citizenship Studies 839; Linda Lumayag, 'A Question of Access: Education Needs of Undocumented Children in Malaysia’ (2016) 40(2) Asian Studies Review 192.

61 Where there was a case that could fit into more than one category, an evaluation of the dominant reason why the person could not obtain citizenship was identified. For example, while many cases were affected by the lack of documentation, if the reason for statelessness also was the child was born prior to the parents getting married, the lack of marriage was seen as the dominant reason. It was only those cases that were solely premised on lost or missing documentation and no other reason that were counted in the documentation category. As well, many lawyers, stateless persons and NGO persons discussed the same case with me. I counted the case once, despite the fact that many persons may have brought it to my attention. Where the case was brought up by the stateless person, this is where the case is counted. In other circumstances, I counted the case with the person who could give me the most details about the case.

62 Federal Constitution (Malaysia) s 14(1). 
character', and have elementary knowledge of Malay. ${ }^{63}$ While there is a pathway to citizenship for those who have been living in Malaysia since before its legal existence, there appears to be a large number of persons who are stateless despite their genuine and lengthy connection to the Federation of Malaysia. While this study identified four cases, one NGO identified 12,400 persons of Indian Tamil descent that are stateless despite their link to Malaysia pre-independence. ${ }^{64}$ There are two subcategories: those that worked in historical plantations and those that did not. To be clear, this category of stateless persons includes persons who were in Malaysia during British colonial times and their descendants. While there currently are plantations in other parts of Malaysia (for example in Sabah) that employ migrant workers, these contemporary plantation workers and their descendants (who may be stateless) do not fall within this category.

\section{Persons Working in Historical Plantations During Colonial Times and Their Descendants}

Recent mapping done by UNHCR and an NGO working on eradicating statelessness amongst those of Indian descent has identified a significant Indian Tamil population that has no citizenship in Malaysia. ${ }^{65}$ Statelessness in this group is attributed to generations of Indian Tamils living in Malaysia at remote, rural plantations. ${ }^{66}$ Large groups of Indian Tamil persons came to Malaysia before Malaysia gained independence and worked in plantations where there was no need for identification or birth registration. ${ }^{67}$ Plantations were self-contained communities that had employment, schools, health centres, and other amenities. ${ }^{68}$ People would marry and go on with life without the need for formal documentation on plantations. ${ }^{69}$ When plantations were shut down, people started moving from rural to urban settings and found themselves confronted with issues in obtaining services, such as education and health services, because they did not have an identification card. 70

In this population, some families have existed in Malaysia over several generations and yet have no documentation to show their citizenship or tie with the country. As part of a registration campaign, the UNHCR and an NGO identified at least 12,400 stateless persons in Malaysia of Indian Tamil descent. This campaign notably assisted 12,000 of those persons to register applications for citizenship to the National Registry Department resulting in 2,300 persons acquiring and confirming nationality. Only 12 per cent of cases have been resolved successfully meaning that approximately 9,700 persons are still awaiting a decision on their registration of citizenship. The Malaysian

63 ibid ss 16, 16A.

64 Appendix Table 3, Interview with 12NGO.

65 Appendix Table 3, Interview with 1NGO; Appendix Table 3, Interview with 4NG. See also United Nations High Commissioner for Refugees, 'Ending Statelessness in Malaysia' $<$ http://www.unhcr.org/en-my/ending-statelessness-in-malaysia.html $>$.

66 Appendix Table 3, Interview with 1NGO; Appendix Table 3, Interview with 4NGO.

67 ibid.

68 ibid

69 Appendix Table 3, Interview with 6NGO.

70 ibid. 
Government has acknowledged the existence of this stateless population having launched the Malaysian Indian Blueprint. ${ }^{71}$

While many of the documented cases are of Indian Tamils in Malaysia, there is a population of Filipinos and Indonesians in Sabah who work in the forestry and palm oil plantations that came during pre-independence that may be eligible for citizenship. ${ }^{72}$ There has been little mapping or extensive effort to identify the extent of the problem of statelessness in this population. ${ }^{73}$ This provides an important research and advocacy opportunity.

Cases of those having long-standing habitual residence in Malaysia arose in my interviews. For example, $2 \mathrm{~S}$ is a 33 -year-old who is a stateless descendant of plantation workers. $2 \mathrm{~S}$ is stateless because her mother is also stateless, despite the fact $2 \mathrm{~S}$ 's mother was a citizen during colonial times. $2 \mathrm{~S}$ indicated that after Malaysia became independent, her mother did not go to the National Registration Department to obtain her identification card detailing her Malaysian citizenship. $2 \mathrm{~S}$ reasoned that her mother did not bother because she did not have her birth certificate. While 2S's father was also a Malaysian citizen, her parent's marriage was not registered because 2 S's mother didn't have an identity card and therefore could not register the marriage. The lack of registration meant that $2 \mathrm{~S}$ could not benefit from acquiring citizenship from her father since she was a child born out of wedlock. $2 \mathrm{~S}$ has applied for citizenship four times with the last attempt in 2017 and her application is still pending. ${ }^{74}$

\section{Persons Not Living on Plantations During Colonial Times and Their Descendants}

The interviews revealed stories of persons and families rendered administratively stateless mainly because they did not register or apply for the appropriate documentation after Merdeka Day or Malaysia Day. Some stories included persons who did not live in plantations.

One NGO provided details of a story about a 70-year Chinese man who was in immigration detention and stateless despite efforts on both the NGO and government to verify the man's identity. ${ }^{75}$ The man's fingerprints were not in any government system and there were no records of his existence. A newspaper advertisement was taken out to find any person who could verify the man's identity but no one responded. While the man has been released from detention, he has not been able to obtain the proper paperwork to verify his identity or acquire citizenship. ${ }^{76}$

71 See Razali (n 1) 5, citing Barisan Nasional, Malaysian Indian Blueprint (Policy Report, 2018).

72 Appendix Table 3, Interview with 1PhD; Ruben Sario, 'Small Filipino community makes big impact on Sabah's landscape' The Star (16 September 2017) $<$ https://www.thestar.com.my/metro/metro-news/2017/09/16/small-filipino-communitymakes-big-impact-on-sabahs-landscape/>; Appendix Table 3, Interview with 2A; Appendix Table 3, Interview with 13NGO.

73 There has been some research. See, eg, Greg Acciaioli, Helen Brunt and Julian Clifton, 'Foreigners Everywhere, Nationals Nowhere: Exclusion, Irregularity, and Invisibility of Stateless Bajau Laut in Eastern Sabah, Malaysia' (2017) 15(3) Journal of Immigrant \& Refugee Studies 232.

74 Appendix Table 2, Interview with 2S.

75 Appendix Table 3, Interview with 3NGO.

76 ibid. 
Another NGO and a lawyer detailed a case where three generations of persons within one family are stateless: the grandmother, her daughter and her grandchild. ${ }^{77}$ As the grandmother was born and had been living in Malaysia since pre-independence, she is entitled to citizenship. The problem was she did not have any paperwork attesting to this fact and therefore could not obtain citizenship herself, and therefore transfer citizenship to her children like other Malaysians.

Still another case that illustrates the generational problem is one described by 1L, who detailed how a child was rendered stateless because the child's birth had not been registered, despite the fact that both of his parents have Malaysian citizenship (from pre-independence). Despite repeated attempts to obtain citizenship for the child, he has been denied and the reason is unknown. ${ }^{78}$

In all of these cases, the issue is not whether such persons are deserving of citizenship, since they have a constitutional right to citizenship and all have a genuine and effective link to Malaysia by virtue of their long-standing residence in Malaysia stemming from pre-independence times.

\section{B People Who Lack Documentation}

As other researchers have noted, 'long-term exclusion and problems in acquiring birth certificates and other documents mean that many children are considered to be "at risk" of statelessness'. ${ }^{79}$ In Malaysia, it appears that there are persons who are stateless simply because they do not have the appropriate documentation to help them obtain citizenship. Eleven of 60 cases documented in this study exhibited the primary issue of statelessness was a lack of documentation. In many of the cases, the documentation that was missing mainly involved birth certificates and marriage certificates. However, even where a person had a birth certificate, sometimes the information on the birth certificate was lacking, such as who the parents of a child were, thus prompting a search for other documentation such as a DNA test or other proof that the child was that of a particular parent. While it is true that lack of documentation may intersect with other causes of statelessness (as discussed below, such as laws that discriminate on the basis of gender, and the lack of marriage registration) it is important to point out that documentation alone can be a substantive barrier to acquiring citizenship.

$6 \mathrm{~S}$ is an 18-year-old girl. She and her 12-year-old brother are stateless. $6 \mathrm{~S}$ told me that both of her parents are Malaysian citizens, married and have a total of six children. $6 \mathrm{~S}$ and two of her siblings are stateless. Her father is deceased and her mother had lost all of her important documents many years ago between the time her third sibling and fourth sibling were born, which explains why her older siblings have citizenship. 6S told me that it was difficult to apply for citizenship because she did not have the required documents since her mother had lost them and was unable to obtain new copies. With the help of a paralegal, she has gathered other documents that she hopes will help her citizenship application such as her father's death certificate which detailed his citizenship

77 Appendix Table 3, Interview with 6NGO; Appendix Table 3, Interview with 1L.

78 Appendix Table 3, Interview with 1L.

79 Allerton, 'Contested Statelessness in Sabah' (n 2) 257; see also Allerton, 'Statelessness and the Lives of the Children of Migrants in Sabah' (n 60); Razali, Nordin and Duraisingam (n 5). 
and her older siblings' identification which details their citizenship. She has applied for citizenship but is waiting for a response. ${ }^{80}$

$14 \mathrm{~S}$ is a 32-year-old woman whose birth certificate indicates that her citizenship is 'belum ditentukan' or not specified. 14S's birth certificate does not have any details regarding her father and is missing the citizenship information of her mother. Since her parents were not married, 14S's citizenship follows her mother but since her mother could not substantiate her citizenship at the time of her birth registration, 14S does not have Malaysian citizenship. 14S subsequently married a Malaysian citizen and had three children with him. Two of those children are not citizens because her marriage was not registered before the births of the two older children. The third child was born after 14S's marriage was registered and therefore her youngest child inherited his father's Malaysian citizenship. 14S has been able to find her mother's birth certificate, which identifies her mother as a citizen. She applied for citizenship in 2011 with this new document but was rejected. She and her two older children remain stateless. ${ }^{81}$

$15 \mathrm{~S}$ is a 63 -year-old woman of Indian Tamil descent who holds a permanent residence card even though her mother (aged 86) is a Malaysian citizen and her three siblings have Malaysian citizenship. 15S does not know why she does not have Malaysian citizenship. Her mother, ten years ago, lost her birth certificate, and has made efforts by attending three separate registration offices to get a new one but has not been able to. ${ }^{82}$

In these cases, again, the question is not one of entitlement - persons in this category have a legal entitlement and also genuine and effective links to Malaysia but lack the documentation to substantiate these links. A more proactive role on the part of the government to assist in providing documentation and also infusing flexibility in decision-making would assist this group of persons. This aspect of this research project will be explored in greater detail in forthcoming work.

\section{Abandoned Children or 'Foundlings' and Adopted Children}

An overriding theme arising out of my discussions with interview participants was how statelessness is prevalent among abandoned and adopted children. Fifteen of the 60 cases identified for this study dealt with abandoned and/or

80 Appendix Table 2, Interview with 6S.

81 Appendix Table 2, Interview with 14S.

82 Appendix Table 2, Interview with 15S. 
adopted children. Reported case law also reveals stateless cases coming to the courts dealing with abandoned and adopted children. ${ }^{83}$

A number of persons working with NGOs in Malaysia work with abandoned children. Two NGOs directly provide services for abandoned children. One interviewee from one of the NGOs noted that 90 percent of the hundreds of cases of abandoned children that came to her in the last decade are stateless. ${ }^{84}$ Statelessness is persistent among abandoned children or 'foundlings' in Malaysia because they often come to NGOs without any documentation or information about their background. ${ }^{85}$

A related but overlapping category with abandoned children is adopted children. Some abandoned children are adopted by persons in Malaysia. A stateless child who is adopted by Malaysian parents does not always obtain citizenship automatically. ${ }^{86} \mathrm{~A}$ few stateless adopted children shared their stories with me.

$3 \mathrm{~S}$ is a 21-year-old who was born in Malaysia and was adopted by two Malaysian citizens. She told me she does not know anything about her biological parents other than they may be Filipino. 3S said she realised she was stateless when she was 12 years old and could not get an identity card. She applied for citizenship then and was rejected. 3S applied for citizenship again when she was 13 after being re-issued a birth certificate that stated she was not a citizen. This application took 8 years to reach a decision. 3S told me after my first interview with her that she received a negative decision. ${ }^{87}$

5S was born in Malaysia and was adopted by Chinese parents who are also Malaysian citizens. 5S stated that the only thing she knows about her biological mother is that she is Filipino. She does not know where her mother is or any information regarding her father. $5 \mathrm{~S}$ learned she was stateless when her mother accompanied her to the registration office at the age of 12 to obtain her identity card. The Malay officer commented that she did not look like her Chinese mother and told her that her birth certificate was fraudulent. The officer told $5 \mathrm{~S}$ that she needed to be properly adopted. 5S's parents did go through the adoption process and $5 \mathrm{~S}$ was issued a new birth certificate as a result, but the birth certificate stated she had no citizenship. 5S said she applied three times for

83 Yu Sheng Meng (A Child Represented by His Litigator, Yu Meng Queng) v Ketua Pengarah Pendaftaran Negara \& Ors [2016] 7 MLJ 628 (Asmabi Mohamad J) (High Court of Malaya); Foo Toon Aik (Suing on His Own behalf and as Representative of Foo Shi Wen, Child) v Ketua Pendaftar Kelahiran dan Kematian, Malaysia [2012] 9 MLJ 573 (Rohana Yusof J) (High Court of Malaya); Lee Chin Pon \& Anor v Registrar-General of Births and Deaths, Malaysia (Unreported, Application for Judicial Review No R1-25-343-08, High Court of Malaya, 16 December 2009); Leong Peng Kheong \& Anor v Registrar-General of Births and Deaths, Malaysia (Unreported, Application for Judicial Review No 25-10205/2014 and 25-103-5/2014, High Court of Malaya, 29 July 2015); Than Siew Beng \& Anor $v$ Ketua Pengarah Jabatan Pendaftaran Negara \& Ors [2015] MLJU 2059 (Unreported, High Court of Malaya); Than Siew Beng \& Anor v Ketua Pengarah Jabatan Pendaftaran Negara \& Ors [2017] MLJ 662 (David Wong, Badariah Sahamid and Harmindar Singh JJCA) (Court of Appeal); Chin Kooi Nah (Suing by Herself and as Next of Kin to Chin Jia Nee, An Infant) v Pendaftar Besar Kelahiran dan Kematian, Malaysia [2016] 7 MLJ 712 (Collin Sequerah JC) (High Court of Malaya); Pendaftar Besar Kelahiran dan Kematian, Malaysia v Pang Wee See [2017] 3 MLJ 308 (Abang Iskandar, Zamani A Rahim and Zaleha Yusof JJCA) (Court of Appeal).

84 Appendix Table 3, Interview with 10NGO.

85 Appendix Table 3, Interview with 8NGO.

86 Appendix Table 3, Interview with 1L; Appendix Table 3, Interview with 5L.

87 Appendix Table 2, Interview with 3S. 
Malaysian citizenship and each time she was denied. Her fourth application was submitted in 2016 and she is still awaiting a result. ${ }^{88}$

17S (Malaysian citizen of Chinese ethnicity) is the mother of a 14-year-old stateless girl. She detailed how she adopted her daughter from a clinic known for delivering babies by mothers who did not want to keep their babies. She said that the biological mother of her daughter is of Chinese ethnicity and was unwed. $17 \mathrm{~S}$ says there is no information about the biological father other than that the biological parents were not married. When her daughter was around 12 years old, she took her to obtain her identity card at the registration office and discovered that her daughter's birth certificate was fraudulent. The officer at the registration office told her that the clinic where her daughter was born was notorious for producing fraudulent documents and it raised a red flag with the registration office. The officer took the fraudulent birth certificate away and issued another one listing the child as a non-citizen. $17 \mathrm{~S}$ engaged with a lawyer she read about online who represented stateless children. This lawyer assisted $17 \mathrm{~S}$ in the legal adoption of her daughter and helped 17S's daughter obtain a new birth certificate with $17 \mathrm{~S}$ 's name on it as a parent. The new birth certificate lists $17 \mathrm{~S}$ 's daughter as a non-citizen. She is now judicially reviewing this third birth certificate. ${ }^{89}$

3L is a lawyer representing a stateless child, born in Malaysia, who was adopted by her two parents who are Malaysian citizens. The client's biological parents were a Malaysian citizen and an Indonesian citizen. The lawyer brought an originating summons to declare her client a citizen and at the High Court level, the Court stated that the child was Indonesian. This case is currently being appealed to the Court of Appeal. 90

$6 \mathrm{~L}$, another lawyer, explained that an NGO refers stateless cases to her to process adoptions of stateless persons or obtain legitimacy orders. $6 \mathrm{~L}$ told me about a particularly troubling case wherein her client, a father of a stateless child, adopted his biological child in the hopes this would help the child obtain citizenship. The father, a Malaysian citizen of Indian ethnicity, was in a relationship with an Indonesian citizen who gave birth to their child. She subsequently left him with the child and left Malaysia and is untraceable. The child's birth certificate details no names of the parents. Despite the father providing a DNA test to show he is the biological father of the child, he was still advised to adopt the child legally as, in law, his daughter was not seen as his legitimate child. This child was able to get citizenship in the end. ${ }^{91}$

In this category, abandoned and adopted children should be able to benefit from the law in that they are all born within the Federation of Malaysia and also have a legal parent that is a Malaysian citizen. As 5L noted, when litigating such cases, the factual finding that a stateless person was born in Malaysia is rarely contested because birth certificates and adoption or legitimisation orders provide the documentary proof of birth within the country. In these cases, then, this fact of being born in Malaysia coupled with the intention and long-standing residence in the country provides a genuine and effective link to support citizenship by operation of law. As well, many cases also possess factual findings of a legal parent who is a Malaysian citizen, a further genuine and effective link.

88 Appendix Table 2, Interview with 5S.

89 Appendix Table 2, Interview with 17S.

90 Appendix Table 3, Interview with 3L.

91 Appendix Table 3, Interview with 6L. 
D Children of 'Mixed' Marriages or Alternative Families and Cases Where

Children Are Born Out of Wedlock or before a Marriage Was Registered

This category brings together cases involving stateless children where their entitlement to Malaysian citizenship arises from the fact that they were:

(a) Born of parents where the father is a Malaysian citizen and the mother is not; and

(b) Born of parents who were not legally married at the time of their birth.

It is important to note that these legal qualifications entrench gender discrimination in Malaysian citizenship law, providing preferential treatment to married couples and, where couples are not married, denying children the opportunity to acquire citizenship by descent from their father.

Twenty of the 60 cases unearthed in this study involved children who are stateless because of the marital or lack of marital status of their parents or the timing of the legal recognition of the marriage. These circumstances arise due to various reasons including: the divorce of the first marriage was not finalised, delaying the second marriage; the parents did not know the importance of legitimising/registering the marriage (even though a customary or religious marriage, or a marriage in a foreign place had taken place) before a child was born; and/or the parents had never been married not knowing the significance of marriage to a child's citizenship.

In reviewing the cases below, it is important to understand that like the above categories, there is often no question that the child has a genuine and effective link to Malaysia. These links are substantiated by the fact that a child is born in Malaysia and/or born to one Malaysian parent.

Still, some legal practitioners will point to the gendered restriction that the child's citizenship follows the mother where the child is considered 'illegitimate'. Where the child is born in Malaysia however and is de jure stateless, this is all that matters. The question of whether or not the child has a 'blood' right to citizenship is irrelevant under the Federal Constitution. As long as the child is born in Malaysia, and is not a citizen of any other country, that is all that is needed to gain citizenship by operation of law. Two subcategories will be explored below: children of mixed marriages or alternative families and children born out of wedlock or before a marriage was registered.

\section{$1 \quad$ Children of Mixed Marriages or Alternative Families}

Children born to alternative family arrangements or born outside of Malaysia to married parents where the mother is a Malaysian citizen and a father who is not a Malaysian citizen may find themselves stateless.

One NGO described cases arising from children born in alternative family situations involving non-Muslim persons in Malaysia. ${ }^{92}$ Chinese persons are not able to have multiple marriages registered or engage in polygamy (Muslims are legally permitted to have multiple marriages). Despite this formal restriction, some Chinese men did have relationships with persons they were not formally married to but customarily married to and had children with multiple wives.

92 Appendix Table 3, Interview with 6NGO. 
Children born of women who are not Malaysian citizens, and who were not legally married to the father (who is a Malaysian citizen) may not be recognised as citizens.

1S spoke to me about how his stateless status resulted from an alternative family arrangement where his father, a Malaysian citizen of Chinese descent, was married to his first wife, but engaged in a relationship with his mother, a Filipino citizen. 1S was born in Sabah, Malaysia, but because 1S's parents were not married and his mother is not a Malaysian citizen, his birth certificate indicated he did not have any status. 1S's parents are both deceased: his father died when he was around 8 years old and his mother died when he was around 15 years old. 1S has applied for citizenship twice. His first application was rejected, and his second application, submitted in 2014, is still under consideration. 1S indicated to me that he was born in Malaysia and has never been to the Philippines and has no connection to the Philippines. 93

$13 \mathrm{~S}$ (Chinese descent with Malaysian citizenship) is the father of a young child from a relationship he had with a Thai woman. 13S was not married and his daughter was born in Thailand. 13S stated that he went to Thailand to bring his child back to Malaysia and, before doing so, obtained a birth certificate in Thailand. When the child was two years old, $13 \mathrm{~S}$ tried to obtain citizenship for his daughter but an officer at the registration office said that he did not have the requisite documents. $13 \mathrm{~S}$ made efforts to visit the Thai embassy to have the documents he had translated and authenticated, but even with this, the registration office denied him the opportunity to apply for citizenship. 13S found out about a registration drive happening in Penang and decided to come to see if he could apply for citizenship. He applied for citizenship on behalf of his daughter during this event and is awaiting an answer. ${ }^{94}$

$3 \mathrm{~L}$ told me that in her legal practice, most stateless cases involve mixed marriages. For example, she explained that she had a number of clients who were Chinese men who married Indonesian, Thai, Cambodian or Filipino women. 3L spoke about one successful case she worked on where she was representing a Chinese man who had a child with a Filipino woman. The mother of the child is no longer in the child's life and he could not trace or find her. This child was able to obtain citizenship by originating summons, seeking a declaration he was a citizen. ${ }^{95} 3 \mathrm{~L}$ said she is currently representing another Chinese man who has a child with a Filipino woman. She detailed how her client applied for citizenship for the child three times and each time he was rejected. This case is pending in the court system. ${ }^{96}$

\section{Children Born Out of Wedlock or before a Marriage Was Registered}

Children who have two parents who were not married at the time of their birth may find themselves stateless despite the fact one parent may be a Malaysian

93 Appendix Table 2, Interview with 1S.

94 Appendix Table 2, Interview with 13S.

95 Navin A/L Moorthy v Ketua Pengarah Pendaftaran Negara, Malaysia \& Ors Malaysia (Unreported, High Court of Malaya, Originating Summons No: 24NCvC-2011-12/2013); Ida Lim, ‘After 17 Years, Stateless Teen Finally Recognised As Malaysian' Malaysia Mail Online (6 April 2016) <http://www.themalaymailonline.com/malaysia/article/after-17years-stateless-teen-finally-recognised-as-malaysian>.

96 Appendix Table 3, Interview with 3L. 
citizen. ${ }^{97}$ This is especially true of children born to unwed parents where the mother does not have Malaysian citizenship and the father does have Malaysian citizenship. ${ }^{98}$ Reported case law also shows stateless cases dealing with children born before a marriage takes place or is registered. ${ }^{99}$ I spoke with several people in Malaysia exhibiting such examples.

$2 \mathrm{~S}$ spoke about how she could not acquire citizenship despite the fact her father was a Malaysian citizen because her mother was stateless and her parents' marriage could not be registered due to the fact the mother is stateless. ${ }^{100}$

$4 \mathrm{~S}$ is the father of five children from two relationships. One of his children is stateless. $4 \mathrm{~S}$ is a Malaysian citizen and his second wife is an Indonesian citizen. $4 \mathrm{~S}$ told me that he was pursuing a divorce with his first wife at the time he met and engaged a relationship with his second wife. Before his divorce was finalised, and therefore, before he could marry his second wife, one of his daughters was born in Malaysia. Because he was not married to his second wife, and because his wife is not a Malaysian citizen, his daughter could not benefit from acquiring Malaysian citizenship from her Malaysian father. 4S told me the registration of his marriage in Malaysia took approximately one year to complete and it required traveling to Indonesia twice to acquire the appropriate documentation. After registering his marriage, he tried to apply for citizenship for his daughter but the registration office advised him, at different times, to adopt his daughter, to seek legal advice, and to wait until his daughter is 12 years old when she is eligible for an identity card. 4S told me his daughter was born in 2005 and, in 2015, he applied for citizenship on her behalf. This application was rejected. In 2016, he applied for citizenship for his daughter again. She is currently still waiting for a decision and has not been able to attend school because the school requires a passport for his daughter to attend. $4 \mathrm{~S}$ explained that his daughter has never been to Indonesia and has lived her entire life in Malaysia. ${ }^{101}$

9S is a woman who is a Thai citizen and has three children born in Malaysia, one of which is stateless. 9S was married to a Chinese person who had Malaysian citizenship. He passed away one year ago. 9S stated her oldest child, who is 17 years old, is stateless because she was born after her marriage was registered. 9S said she attempted several times to register her marriage before her oldest child was born but that the registration office did not believe her marriage certificate from Thailand was authentic. 9S had to make several attempts with her certified and translated marriage certificate to get it registered. Her two younger children have citizenship because they were born after the marriage was registered. 9S indicated that she tried to apply for citizenship for her daughter twice previously and that both applications were rejected. She submitted another application for citizenship in January 2018 and is waiting for a reply. ${ }^{102}$

$11 \mathrm{~S}$ (Malaysian citizen of Chinese ethnicity) is a father of a child who is stateless because his marriage to an Indonesian woman was not registered before

97 Appendix Table 3, Interview with 6NGO.

98 Appendix Table 3, Interview with 1L.

99 Madhuvita Janjara Augustin (Suing through Next Friend Margeret Louisa Tan) v Augustin A/L Lourdsamy \& Ors [2018] 1 MJL 307 (Court of Appeal); Lim Jen Hsian \& Anor v Ketua Penegarah Jabatan Pendaltaran Negara \& Ors [2017] 8 MLJ 122 (Asmabi Mohmad J) (High Court of Malaya).

100 Appendix Table 3, Interview with 2S.

101 Appendix Table 2, Interview with 4S.

102 Appendix Table 2, Interview with 4S. 
the birth of his child. He stated that he was married before the child was born. While attending the Jabatan Pendaftaran Negara (the National Registration Department) to seek permission to marry a foreign spouse, $11 \mathrm{~S}$ told the officer that his wife was pregnant and that it was a difficult pregnancy. The officer told him they could register the marriage after the baby was born but did not advise of the consequences of doing this. 11S was angry that the officer advised him of this. He stated that he would have made the effort to register the marriage before the child was born despite difficulties his wife was having. 11S explained he has applied three times for his son's citizenship. He applied in 2012 and again in 2014 and both applications were rejected without reasons. 11S made another application during a registration drive in Penang in February 2018. ${ }^{103}$

13S (Malaysian citizen of Chinese ethnicity) is the father of a stateless child from a relationship with a Chinese woman from China. He was not married to the mother of his child because he was still married to his first wife at the time the child was born. The mother of the child has since returned to China and has no contact with the child. 13S applied for citizenship on behalf of his son in 2013 and waited two years until he received a rejection with no reasons. He was told to just apply again when he went to the registration office to inquire why the application was rejected. He submitted another application during a registration drive in Penang in February 2018. ${ }^{104}$

Similarly, 12S (Malaysian citizen of Chinese ethnicity) is a father who has two children that are stateless because he was not married to a woman with foreign nationality (Thai). Like $11 \mathrm{~S}$ and $13 \mathrm{~S}$, he was applying on behalf of his children during a registration drive in Penang in February 2018. 105

$18 \mathrm{~S}$ is a Balinese woman with Indonesian citizenship. She is married to a Malaysian citizen and has two children, one of whom is stateless. She stated that her oldest child is stateless because the child was born after her marriage was registered, and also because the child was registered late (seven months after the birth). $18 \mathrm{~S}$ explained that she thought that once the marriage was registered, there would be no problem with her oldest child getting citizenship. She has been waiting for five years for a decision. 106

$4 \mathrm{~L}$ is representing a client that was born before her Malaysian father and Papua New Guinean mother were married. She helped her clients put together an originating summons to obtain a declaration for citizenship. At the High Court level, the Court found that the marriage was not legitimised at the time of birth and therefore the child's citizenship follows the mother's. The decision was appealed at the Court of Appeal of Malaysia and was allowed. ${ }^{107}$ The matter is now pending at the Federal Court of Malaysia (the highest court in Malaysia). 4L explained that she had worked on another case with similar facts where the High Court granted a legitimacy order (recognising the child as that of the father's even though the parents are not married) but refused to recognise the child's Malaysian citizenship. 4L explained that they are now applying for citizenship with the declaration of legitimacy, hoping this will lead to a positive outcome. ${ }^{108}$

\footnotetext{
103 Appendix Table 2, Interview with 11S.

104 Appendix Table 2, Interview with 13S.

105 Appendix Table 2, Interview with 12S.

106 Appendix Table 2, Interview with 18S.

107 Madhuvita, (n 99).

108 Appendix Table 3, Interview with 2L.
} 
2L represents clients who had a child before they were married and assisted them in obtaining declaration of legitimacy. In one case, she explained the father was a Malaysian citizen of Indian ethnicity and the mother was a Thai citizen. Even after the declaration for legitimacy was provided, the application for citizenship has been pending for four years. $2 \mathrm{~L}$ reported that the marriage is on the rocks as the stress of the child's situation is affecting everyone in the family emotionally. 109

\section{E Indigenous Persons}

This study did identify two instances of statelessness that affected Indigenous people. One paralegal detailed how he traveled to Sarawak for six months to provide paralegal assistance for 150 Iban people to obtain identity cards. ${ }^{110} \mathrm{He}$ described having to take a bus and then boat to reach this population and that the reason why such a large group of people were stateless was because of their remote rural location, their lack of understanding of the need or importance of obtaining citizenship and resulting identification to obtain services, and also because sometimes village chiefs refused to sign documentation to attest the individuals were people living in the particular village, refusing to acknowledge the need to be part of such systems.

The study recognises a gap in knowledge when it comes to the various Indigenous persons that may be stateless in Malaysia and future research projects in this area are encouraged. This particular study did not delve deeply into investigating how pervasive statelessness is within all the Indigenous groups in Malaysia. Nevertheless, for the purpose of this exploratory study, it is important to acknowledge that this category of stateless persons, like the above categories, also has genuine and effective links to Malaysia by virtue of a generational and long-standing existence and residence within the country. The Federal Constitution acknowledges the special rights attached to Indigenous persons in Malaysia. While Indigenous persons may be stateless due to the same reasons identified above (such as lack of documentation), it is important to recognise Indigenous persons as a separate category because, as ethnic minorities living in isolated areas of Malaysia, they have the added barrier of a lack of access to services that would allow them to potentially access citizenship.

\section{F Refugees and Children of Migrant Workers}

This study also identified eight cases dealing with stateless migrants that have come to Malaysia either as foreign workers or as refugees. It is important to recognise that not all refugees or migrants are stateless, and this study was occupied with only those that were stateless.

109 Appendix Table 3, Interview with 4L.

110 Appendix Table 3, Interview with 2PL. 
One notable group of persons are Filipino and Indonesian migrants in the state of Sabah. ${ }^{111}$ The proximity of the Philippines and Indonesia to Sabah, civil conflicts in the Philippines in the 1970s and 1980s, and the demand for cheap labour in forestry and palm oil industries attracted migration from neighbouring countries. ${ }^{112}$ In Sabah, there are two notable populations of migrant workers: Filipinos and Indonesians. ${ }^{113}$ Migratory flows from the Philippines and Indonesia can be attributed two reasons. The first is a civil conflict in the southern Philippines between 1972 and 1977 forced people to flee. ${ }^{114}$ The Muslim Filipinos that fled to Sabah were recognised as refugees by the UNHCR and initially received special permission to stay and work from Sabah's chief minister. ${ }^{115}$ The second reason is that several industries including forestry and palm oil had a demand for migrant labour driving Sabah to have the highest proportion of foreign workers among Malaysian states. ${ }^{116}$ As a result there are many migrants in Malaysia that have come either as refugees or as skilled workers. They and their family members form part of the stateless population in Malaysia.

$7 \mathrm{~S}$ is an eight-year old girl who was born in Malaysia of parents with Indonesian citizenship. Her parents have lived in Malaysia for ten years. 7S's parents came to Malaysia on a work permit but her father has been without a legal work permit for one year, and her mother without a legal work permit for four years. 7S's parents stated they cannot afford to pay for the work permits. In 2017, 7S's mother applied for citizenship for 7S mainly because 7S was not permitted to go to school and her parents could not afford to send her to private school. ${ }^{117}$

$8 \mathrm{~S}$ was born in Indonesia but claims not to have any Indonesian citizenship. $\mathrm{He}$ is a permanent resident who has lived in Malaysia for 39 years and is married to an Indonesian citizen. $8 \mathrm{~S}$ is the father of five children. All of his children are stateless. $8 \mathrm{~S}$ was referred to a lawyer to investigate whether he is entitled to Malaysian citizenship as a result of his long-standing permanent residence in the country. ${ }^{118}$

A notable group of stateless refugees is the Rohingya from Myanmar. ${ }^{119}$ Approximately 150,000 Rohingya refugees are registered by UNHCR in

111 See generally Azizah Kassim, 'Filipino Refugees in Sabah: State Responses, Public Stereotypes and the Dilemma over Their Future' (2009) 47(1) The Southeast Asian Studies 52; Helen Brunt, 'Statelessness at Sea' in Laura van Waas and Amal de Chikera (eds), The World's Stateless Children (Wolf Legal 2017) 290-94; Asia Pacific Refugee Rights Network, 'The Vulnerability of Bajau Laut (Sama Dilaut) Children in Sabah' (Position Paper, March 2015), $<$ http://www.aprrn.info/1/images/PDF/Bajau_Laut_position_paper_FINAL.pdf $>$; Camilla Olson, 'Malaysia: Undocumented Children in Sabah Vulnerable to Statelessness' Refugees International Bulletin (13 June 2007).

112 See generally Greg Constantine, 'Malaysia: Held in the Shadow of the Sunrise', Nowhere People Stories (Online Exhibition, 2015) <http://www.nowherepeople.org/new-page/>.

113 Allerton, 'Contested Statelessness in Sabah' (n 2) 255.

114 ibid 254-55. See also Kassim (n 111).

115 Allerton, 'Contested Statelessness in Sabah' (n 2) 254-55; Kassim (n 111) 57-58.

116 Allerton, 'Contested Statelessness in Sabah' (n 2) 255.

117 Appendix Table 2, Interview with 7S.

118 Appendix Table 2, Interview with 8S.

119 See generally, Confined Spaces (n 1). 
Malaysia as of 2017, and many are stateless. ${ }^{120}$ In one case, $2 \mathrm{~L}$ represented a Rohingya child that was born in Malaysia to obtain travel documents but was unsuccessful because she was stateless. The child has serious medical issues and a German NGO wanted to bring the child to Germany but was unable to because the child was stateless and could not acquire refugee status at the very least through UNHCR. 2L indicated that the German NGO gave up on transporting the child and has assisted the child in Malaysia. ${ }^{121}$

9NGO works primarily with refugees in Malaysia and identified that, other than Rohingya, the main groups of stateless refugees include: Palestinian, Syrian and Thai. 9NGO revealed that many refugees are not preoccupied with obtaining citizenship in Malaysia but are more concerned about obtaining refugee status, and access to basic services such as health care and education since refugee status is not always given by UNHCR. 11NGO, also an organisation that works with refugees, substantiated this by saying that some refugees see Malaysia as a pit stop to other locations, and some would like to stay but recognise they must earn their right to citizenship and are more preoccupied with daily survival like obtaining a job and education for their children. $11 \mathrm{NGO}$ stated that many refugees don't understand the concept of statelessness and don't realise they are stateless. Further he surmised the majority didn't care about statelessness but cared more about obtaining work, education and access to health care. 9NGO revealed that very few refugees obtain permanent residency or citizenship and those that do, do it through marriage. In other words, they obtain it by proving a genuine and effective link by marrying Malaysian citizen. ${ }^{122}$

In some of these cases, long-standing residency in Malaysia may allow migrants and refugees to eventually qualify for citizenship but it is not an automatic conferral. Migrants and refugees must apply through the naturalisation process (which poses requirements on applicants) or apply through registration (if they meet those requirements, such as marrying a Malaysian citizen, speaking Malaysian sufficiently and residing in Malaysia for a period of time). ${ }^{123}$ Persons in this category then are not de facto Malaysian citizens and may be citizens of other countries. If there are migrants and refugees in Malaysia that are stateless then they are genuinely stateless and the issue of resolving their nationality may reside in mining their migratory history to understand whether or not they have citizenship elsewhere. Their status as stateless on its own does not give them any automatic entitlement to citizenship in Malaysia and the reason resides in the fact that they do not possess any genuine or effective link as recognised in the Federal Constitution. They may attempt to obtain Malaysian citizenship through the naturalisation or registration processes by meeting the stated requirements that are the legal manifestations of a genuine and effective link. However, these processes do not provide a guarantee to obtaining citizenship and it is often extremely difficult for refugees or other migrants to meet requirements of the naturalisation process.

Malaysia is not a signatory to Refugee Convention and the decision as to whether to recognise a group of persons as refugees is highly political. It is

120 Adam Bemma, 'Malaysia: A Rohingya Safe Haven?' Aljazeera (Kuala Lumpur, 23 November 2017) < https:/www.aljazeera.com/news/2017/11/malaysia-rohingya-safe-haven171122190637814.html>.

121 Appendix Table 3, Interview with 2L.

122 Appendix Table 3, Interview with 9NGO.

123 Federal Constitution (Malaysia) art 19. 
widely understood that the reason why the Filipinos in Sabah in the 1980s and the Rohingya are allowed to be recognised as refugees is because they are Muslim. ${ }^{124}$ Malaysia has made some positive statements with its Association of Southeast Asian Nations ('ASEAN') counterparts supporting Rohingya refugees and allowed the UNHCR to register them as refugees. However, other refugee groups may not eligible for registration with the UNHCR and the issue of a durable solution for any refugee within Malaysia does not appear to be an option. ${ }^{125}$ Thus, other persons, who may be stateless, may not be able to access refugee protection. Further, despite the conferral of refugee status, there is no pathway for permanent residence or citizenship. One Rohingya woman I listened to in a talk described how she had lived in Malaysia for over 20 years and still has no hope of obtaining citizenship. ${ }^{126}$

\section{$\mathrm{G} \quad$ Intersection of Factors}

It is important to note that for some stateless persons, they may encounter their status as stateless in a multitude of ways or via an intersection of factors. For the purposes of this study, where there was a cause of statelessness attributed to a reason other than lack of documentation, that reason was deemed the primary reason. An example where an intersection exists is with 16S: a 33-year-old woman whose birth in Malaysia outside of a hospital led to the late registration of her birth (14 years later). Her father is a Malaysian citizen but her mother, while born in Malaysia, did not possess a birth certificate or identity card. 16S's mother was adopted and was unable to acquire any documentation about herself. Due to the lack of documentation, 16S's parents were unable to get married. $16 \mathrm{~S}$ is stateless on a few different axes: she is an 'illegitimate' child born out of wedlock to a non-citizen, her birth was registered late and her mother did not have the appropriate documentation due to abandonment and adoption. ${ }^{127}$

Another example is a case described by $5 \mathrm{~L}$ that involved two Malaysian citizens adopting a child. The child was adopted through a clinic for a fee. The clinic had provided the adopted parents with the child's birth certificate that listed the adopted parents as natural parents of the child. When the parents went to the registration office with the child to obtain his identity card, the registration office identified the birth certificate as fraudulent, cancelled the first birth certificate and issued a new one listing the parents as unknown and the child as not a citizen. 5L helped the family do a legal adoption and obtained a new, third birth certificate. While listing the adopted parents, this new birth certificate listed the child as a permanent resident. 5L helped the family judicially review the decision made on the third birth certificate that the child was not a citizen and

124 Allerton, 'Contested Statelessness in Sabah' (n 2) 261; Mayuko Tani, 'ASEAN Aims to Express "Concern" on Rohingya Crisis for First Time' Nikkei Asian Review (Singapore, 13 November 2018) <https://asia.nikkei.com/Politics/International-relations/ASEAN-aims-toexpress-concern-on-Rohingya-crisis-for-first-time>; RF Dorall, 'Muslim Refugees in Southeast Asia, the Malaysian Response' (1988) 1(3) Asian Migration 88.

125 Stephen Dziedzic, 'ASEAN: Malaysian PM condemns inaction of Aung San Suu Kyi over Rohingya "suffering"' ABC News (18 March 2018) < http://www.abc.net.au/news/2018-0318/asean-malaysia-pm-confronts-aung-san-suu-kyi/9560112>.

126 Roundtable on Rohingya in Malaysia: Bridging the Gap Between Aid and Resettlement (Centre for Public Policy Studies, Monash University Malaysia, 6 March 2018) $<$ https:/www.monash.edu.my/news-and-events/pages/latest/articles/2018/a-roundtable-onthe-rohingya-in-malaysia>.

127 Appendix Table 2, Interview with 16S. 
they were successful in obtaining citizenship for the child. 5L has represented several other persons in similar situations. ${ }^{128}$ These cases highlight how a lack of proper documentation and adoption intersect to create administratively stateless persons.

Finally, some persons who were eligible for citizenship by virtue of their long-standing residence since pre-independence also were children who were adopted in plantations by persons who were not their biological parents. ${ }^{129}$ The dual reason of being a descendant of a plantation worker and being adopted complicates a case to ask for citizenship.

\section{The Mirage of a Flood: De Facto Citizens in Malaysia}

The identification of the six categories of stateless persons in Malaysia help us to understand who are stateless persons. This exploratory study suggests that persons who fall within five of the six categories are persons born in Malaysia and have long-standing residence in Malaysia thus indicating a genuine and effective link with the country. Further, the study also suggests that persons in the five of the six categories may also have at least one lawful parent that is a Malaysian citizen, another factor suggesting genuine and effective link to Malaysia. This suggests that the five of the six categories of stateless persons consist of people who did not cross borders, are not foreigners and are not migrants but rather persons who have genuine, effective and substantial links to Malaysia.

There may be legal preoccupation with how the Federal Constitution can be interpreted so as to not open the floodgates to migrants so to speak. ${ }^{130}$ The argument that interpreting the law as it is plainly stated would open the floodgates has no merit for three reasons.

\section{A The Law of Interpretation - Public Policy is Irrelevant Here}

The first is an interpretation reason. Where the text of the Federal Constitution is not clear or express, public policy issues such as whether or not a particular interpretation may lead to unintended consequences may play a role. However, where legal text is clear and express, there is no need to consider public policy. Legal practitioners should follow what is stated, and the law is clear for the five categories of stateless persons in Malaysia.

\section{B Majority of Stateless Persons Have Genuine, Effective and Substantial}

\section{Links}

The second reason is that there is no flood beyond the gates. This paper does not do the work to resolve the number of people that are stateless in Malaysia, which has been a contested subject of debate in public and political discourse. ${ }^{131}$ Instead, the research suggests the number is irrelevant. The focus, as this initial

128 Appendix Table 3, Interview with 5L.

129 Appendix Table 3, Interview with 12NGO.

130 Appendix Table 3, Interview with 5L.

131 See, eg, Eric Paulsen, 'Time to Resolve Malaysian Indian Statelessness', (Lawyers for Liberty, 25 April 2012) <http://www.lawyersforliberty.org/time-to-resolve-malaysianindian-statelessness/>. 
examination suggests, should be on the types of people subject to the plight of statelessness and why. The problem of statelessness is home-grown, indigenous, and one borne by people who have deep roots to the country of Malaysia. The five categories of stateless persons have genuine, effective and significant links to Malaysia. Their link is substantiated by their birth in the federation, and the fact that they are stateless. Further proof of an effective link can point to a 'blood' or legal connection through a parent where necessary but the Federal Constitution does not necessarily require this - the fact of birth in Malaysia with the fact that one is stateless after the first year of one's birth, in law, is sufficient.

\section{There are Built-In Restrictions in the Law for Foreigners}

The third reason is that there are built-in clear restrictions on who and how stateless persons can acquire citizenship. Public discourse in Malaysia reveals a guarded approach to the stateless issue due to a misunderstanding that if citizenship is resolved for any stateless person, then all stateless persons will have access to citizenship no matter what link that person may have to Malaysia. The laws governing citizenship in Malaysia, however, provide restrictions on how foreign nationals may obtain citizenship. For example, migrants and refugees do not qualify automatically by virtue of the fact that they were not born within the Federation. Further, they do not have a Malaysian parent. They must proceed through the naturalisation process if they have no genuine or effective link to Malaysia. For migrants or refugees who marry a Malaysian citizen, there are opportunities for registration as a citizen, but even that process has requirements that the migrant must meet (including number of years of residence; speak Malaysian sufficiently and others) to indicate their genuine and effective link beyond marriage to a Malaysian citizen. ${ }^{132}$

Legal practitioners may point to the children of migrants or refugees who are born in the Federation. It is important to point out that citizenship by operation of law only applies to those born in Malaysia that have no other citizenship. Children who have no parent who is a Malaysian citizen only qualify if they are also stateless following the first year of their birth. There certainly may be cases where there are migrant children who are entitled by operation of law to citizenship but this is because they are stateless and also have no hope of obtaining citizenship from a country other than Malaysia. Substantiating this kind of statelessness is beyond the scope of this paper. The mere opportunity to obtain citizenship elsewhere is not the same as being a citizen of another country. In this sense, while migrants themselves may not be entitled to argue they have a genuine and effective link (unless they have shown long-standing residence), their children may be considered to have such a link by virtue of their birth within Malaysia. The mechanics of how such children (and their parents) may navigate the process to obtain citizenship by operation of law or by naturalisation is outside the scope of this paper.

\section{CONCLUSION}

One academic was interviewed for this exploratory study and indicated that citizenship is a sensitive issue politically in Malaysia, even during the conception

132 Federal Constitution (Malaysia) art 19. 
of the country's constitution. ${ }^{133}$ This paper does not contest the state's rights to determine the parameters of conferring citizenship but it does challenge the misunderstood notion that statelessness is a problem that affects migrants or foreigners only.

This research project suggests that turning to the international principle of dominant and effective nationality can help eradicate statelessness for the majority of stateless persons in Malaysia. This study acknowledges that there are various forms of statelessness and different groups of stateless persons. In order to counter public narratives that statelessness is not a problem, ${ }^{134}$ the law's inclusiveness through a nuanced definition of statelessness can help drive public discourse towards recognising statelessness within local communities in Malaysia instead of recognising pockets of 'exceptionalism'. ${ }^{135}$

Secondly, understanding there are categories of statelessness neutralises the discourse that statelessness is equated with foreignness. The denial of citizenship to administratively stateless persons contributes to the misconceived view that all stateless persons are foreigners and more problematically as 'illegals', 'opportunists', 'cheats' or deviants like 'street children'. ${ }^{136}$ As Catherine Allerton in her research on Sabah writes:

During my research, I noticed how often Sabahans referred not to stateless people but to 'so-called stateless people.' The implication of the 'so-called' prefix seemed to be that people who are described as "stateless" are not really stateless and that this issue is a mirage, obscuring other, more important issues; that is, these are 'so-called' stateless people because their apparent statelessness is simply a mask, both for illegality and for further demographic and political engineering. ${ }^{137}$

A more nuanced understanding of who is stateless may debunk the singular view of stateless persons as illegals or foreigners and therefore tease out sticky notions of who is a legitimate citizen and who is a foreigner. In recognising that stateless persons include administratively stateless, we can view stateless persons not as migrants but as persons with genuine and effective links with the country they are in.

There may be evidentiary problems associated with proving one's statelessness. This is beyond the scope of this paper. In short, however, it should not be a difficult task to substantiate statelessness - a person is stateless if they do not have legal recognition from any other country as a citizen. This fact

133 Appendix Table 3, Interview with 1A.

134 Allerton, 'Contested Statelessness in Sabah' (n 2) 260; 'No Stateless People, Says Zahid' Daily Express (Kuala Lumpar, $20 \quad$ April 2015) $<$ http://www.dailyexpress.com.my/news.cfm?NewsID=99073>.

135 Allerton, 'Contested Statelessness in Sabah' (n 2) 260; Elena Fiddian-Qasmiyeh, 'On the Threshold of Statelessness: Palestinian Narratives of Loss and Erasure’ (2016) 39(2) Ethnic and Racial Studies 301, 303.

136 Fadzilah Majid Cooke and Dayang Suria Mulia, 'Migration and Moral Panic: The Case of Oil Palm in Sabah, East Malaysia' in Oliver Pye and Jayati Bhattacharya (eds), The Palm Oil Controversy in South East Asia: A Transnational Perspective (ISEAS 2013) 140-63; Allerton 'Contested Statelessness in Sabah' (n 2) 264; Eva-Lotta E Hedman, 'Refuge, Governmentality and Citizenship: Capturing "Illegal Migrants" in Malaysia and Thailand" (2008) 43(2) Government and Opposition 358; Alice M Nah, 'Legitimizing Violence: The Impact of Public "Crackdowns" on Migrant Workers and Refugees in Malaysia' (2011) 17(2) Australian Journal of Human Rights 131.

137 Allerton, 'Contested Statelessness in Sabah' (n 2) 261. 
should be taken as substantiated simply by the stateless person's sworn testimony or affidavit declaration. Where such evidence is doubted, it becomes state responsibility to inquire with other states as to the status of a person before denying citizenship. Thus, the paper proposes that for administratively stateless persons, the issue of statelessness is not as problematic as it seems. For administratively stateless persons, it is a matter of the government implementing the law in a way that gives them their entitled recognition as citizens on paper.

While the judiciary should be wary of projecting the status of citizen on a person who has not actually or legally acquired citizenship, in this case, it is not simply the legal entitlement that gives weight to the claim to citizenship by five categories of stateless persons in Malaysia - it is also the genuine, effective and substantial link presented by each of the five groups that tips the balance towards their entitlement to citizenship. It is my hope then, by writing this paper, that lawmakers and policy makers alike look more closely at who is stateless in Malaysia and welcome their fellow compatriots not only socially but legally. 


\section{APPENDIX}

Table 1: Cases of Statelessness

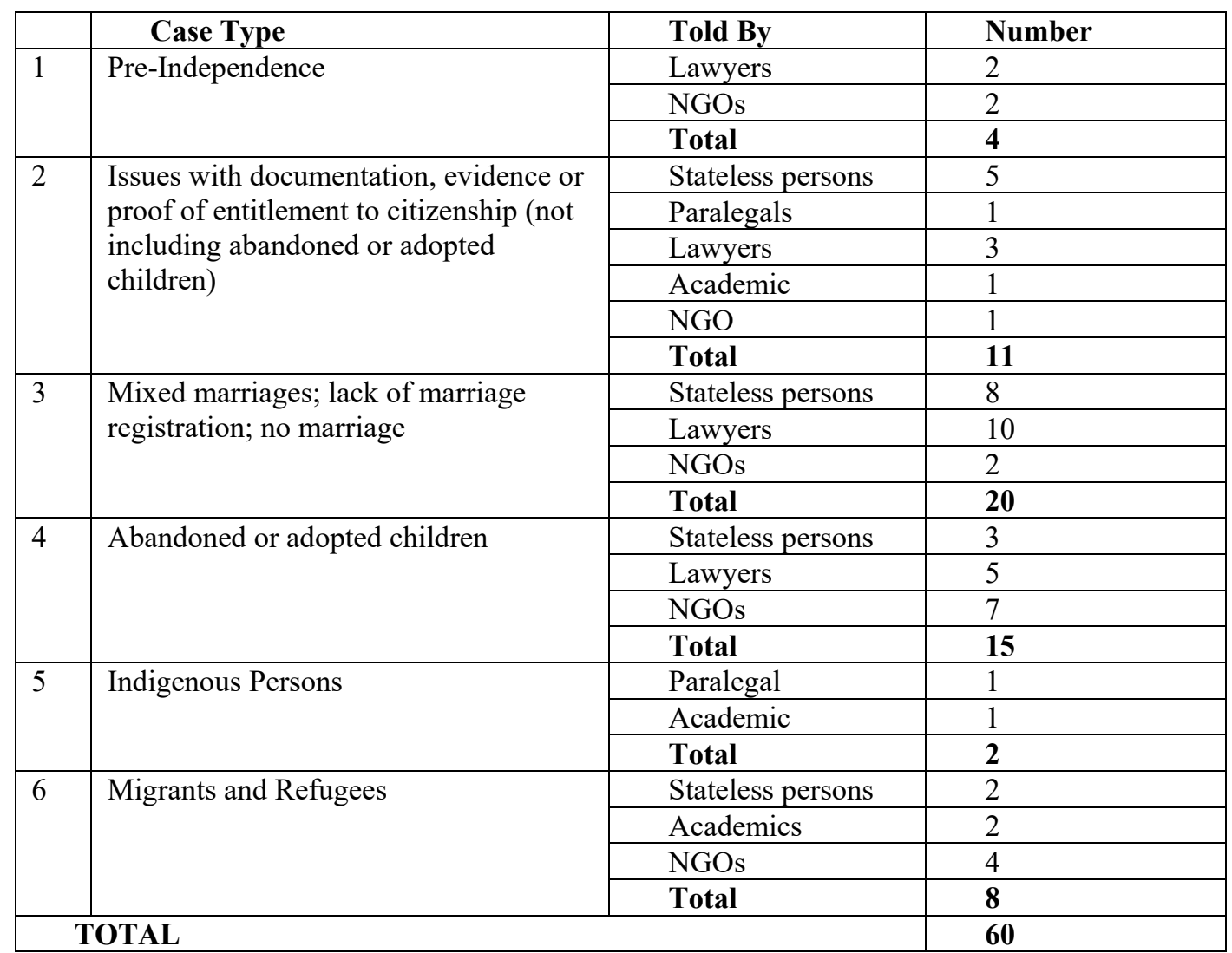

Table 2: Stateless Persons Interviewed

\begin{tabular}{|c|c|c|c|c|}
\hline $\begin{array}{l}\text { Anonymous } \\
\text { Indicator }\end{array}$ & $\begin{array}{l}\text { Circumstances } \\
\text { leading to } \\
\text { statelessness }\end{array}$ & Parents & $\begin{array}{l}\text { How person } \\
\text { discovered } \\
\text { stateless }\end{array}$ & Ethnicity \\
\hline $1 \mathrm{~S}$ & $\begin{array}{l}\text { Chinese father had } \\
\text { second } \\
\text { relationship (no } \\
\text { marriage) with } \\
\text { Filipino woman. }\end{array}$ & $\begin{array}{l}\text { Chinese father } \\
\text { with Malaysian } \\
\text { citizenship and } \\
\text { Filipino mother. }\end{array}$ & $\begin{array}{l}13 \text { years old when } \\
\text { applying for IC }\end{array}$ & $\begin{array}{l}\text { Chinese- } \\
\text { Filipino. }\end{array}$ \\
\hline $2 \mathrm{~S}$ & $\begin{array}{l}\text { Mother lost } \\
\text { identity documents } \\
\text { (from pre- } \\
\text { independence) }\end{array}$ & $\begin{array}{l}\text { Malaysian } \\
\text { citizens of Indian } \\
\text { Tamil descent }\end{array}$ & $\begin{array}{l}\text { Has always known } \\
\text { but tried to rectify } \\
\text { when } 24 \text { years old } \\
\text { when tried to } \\
\text { register her own } \\
\text { birth and obtain } \\
\text { birth certificate }\end{array}$ & Indian-Tamil. \\
\hline $3 \mathrm{~S}$ & Adopted & $\begin{array}{l}\text { Only knows birth } \\
\text { mother is Filipino. } \\
\text { Adopted parents } \\
\text { both Malaysian } \\
\text { citizens. }\end{array}$ & $\begin{array}{l}12 \text { years old when } \\
\text { applying for IC. }\end{array}$ & Malay. \\
\hline $4 \mathrm{~S}$ & $\begin{array}{l}\text { Child born before } \\
\text { marriage }\end{array}$ & $\begin{array}{l}\text { Malaysian father } \\
\text { of Indian-Tamil }\end{array}$ & $\begin{array}{l}\text { Parents knew since } \\
\text { birth due to }\end{array}$ & $\begin{array}{l}\text { Indian-Tamil } \\
\text { and Indonesian. }\end{array}$ \\
\hline
\end{tabular}




\begin{tabular}{|c|c|c|c|c|}
\hline & registered. & $\begin{array}{l}\text { descent and } \\
\text { Indonesian } \\
\text { mother. }\end{array}$ & $\begin{array}{l}\text { difficulties } \\
\text { registering birth. }\end{array}$ & \\
\hline $5 \mathrm{~S}$ & Adopted. & $\begin{array}{l}\text { Speculates } \\
\text { biological mother } \\
\text { was Filipino. } \\
\text { Adoptive Chinese } \\
\text { parents who are } \\
\text { Malaysian } \\
\text { citizens }\end{array}$ & $\begin{array}{l}12 \text { years old when } \\
\text { applying for IC. }\end{array}$ & Half-Filipino. \\
\hline $6 \mathrm{~S}$ & $\begin{array}{l}\text { Lost or no } \\
\text { documents. }\end{array}$ & $\begin{array}{l}\text { Father is Chinese } \\
\text { and mother is } \\
\text { Indian. Both } \\
\text { deceased and } \\
\text { were Malaysian } \\
\text { citizens. }\end{array}$ & $\begin{array}{l}18 \text { years old now. } \\
\text { Has not been able } \\
\text { to go to school for } \\
\text { some time or take } \\
\text { exams due to lack } \\
\text { of identification and } \\
\text { citizenship. }\end{array}$ & Chinese-Indian. \\
\hline $7 \mathrm{~S}$ & $\begin{array}{l}\text { Parents came as } \\
\text { migrants and was } \\
\text { born in Malaysia. } \\
\text { Living in Malaysia } \\
\text { for over } 10 \text { years. }\end{array}$ & $\begin{array}{l}\text { Indonesian } \\
\text { parents }\end{array}$ & $\begin{array}{l}\text { Has not been able } \\
\text { to go to school. } \\
\text { Attending private } \\
\text { religious school } \\
\text { funded by a } \\
\text { political party. }\end{array}$ & Indonesian. \\
\hline $8 \mathrm{~S}$ & $\begin{array}{l}\text { Father a permanent } \\
\text { resident of } \\
\text { Malaysia for } 39 \\
\text { years and mother } \\
\text { Indonesian. } \\
\text { Migrated from } \\
\text { Indonesia. All five } \\
\text { children born in } \\
\text { Malaysia. }\end{array}$ & $\begin{array}{l}\text { Indonesian } \\
\text { mother. Father } \\
\text { does not know if } \\
\text { he has Indonesian } \\
\text { citizenship }\end{array}$ & $\begin{array}{l}\text { Five children have } \\
\text { not been able to go } \\
\text { to school. }\end{array}$ & Indonesian. \\
\hline $9 \mathrm{~S}$ & $\begin{array}{l}\text { Child was born } \\
\text { before marriage } \\
\text { was registered. }\end{array}$ & $\begin{array}{l}\text { Father was } \\
\text { Chinese with } \\
\text { Malaysian } \\
\text { citizenship (now } \\
\text { deceased) and } \\
\text { mother is Thai. }\end{array}$ & $\begin{array}{l}\text { Had issues } \\
\text { registering birth. } \\
\text { Two younger } \\
\text { siblings not } \\
\text { stateless. }\end{array}$ & Chinese-Thai. \\
\hline $10 \mathrm{~S}$ & $\begin{array}{l}\text { Child was born } \\
\text { before parents } \\
\text { were married. }\end{array}$ & $\begin{array}{l}\text { Mother is } \\
\text { Malaysian of } \\
\text { Chinese decent } \\
\text { and Father is } \\
\text { Chinese. }\end{array}$ & $\begin{array}{l}\text { Had issues } \\
\text { registering child in } \\
\text { school. Child not } \\
\text { aware stateless. }\end{array}$ & Chinese. \\
\hline $11 \mathrm{~S}$ & $\begin{array}{l}\text { Child born after } \\
\text { marriage } \\
\text { registered. }\end{array}$ & $\begin{array}{l}\text { Father Malaysian } \\
\text { of Chinese } \\
\text { descent and } \\
\text { mother is a } \\
\text { foreigner (not } \\
\text { known). }\end{array}$ & $\begin{array}{l}\text { Found out child } \\
\text { stateless when } \\
\text { registering son's } \\
\text { birth. }\end{array}$ & $\begin{array}{l}\text { Chinese and } \\
\text { unknown. }\end{array}$ \\
\hline $12 \mathrm{~S}$ & $\begin{array}{l}\text { Child born outside } \\
\text { of wedlock. Father } \\
\text { was still married to } \\
\text { first wife and } \\
\text { divorce not } \\
\text { finalized before } \\
\text { child born with } \\
\text { second partner. }\end{array}$ & $\begin{array}{l}\text { Father is } \\
\text { Malaysian } \\
\text { (Chinese) and } \\
\text { mother is Chinese } \\
\text { (China). }\end{array}$ & $\begin{array}{l}\text { Found out when } \\
\text { registering child's } \\
\text { birth }\end{array}$ & Chinese. \\
\hline $13 \mathrm{~S}$ & $\begin{array}{l}\text { Child born in } \\
\text { Thailand of } \\
\text { Malaysian father }\end{array}$ & $\begin{array}{l}\text { Father is } \\
\text { Malaysian } \\
\text { (Chinese) and }\end{array}$ & $\begin{array}{l}\text { Found out when } \\
\text { brought daughter } \\
\text { back to Malaysia }\end{array}$ & Chinese-Thai \\
\hline
\end{tabular}




\begin{tabular}{|c|c|c|c|c|}
\hline & $\begin{array}{l}\text { (Chinese) and Thai } \\
\text { mother. }\end{array}$ & mother is Thai. & $\begin{array}{l}\text { and tried to register } \\
\text { her birth. }\end{array}$ & \\
\hline $14 S$ & $\begin{array}{l}\text { Mother ( } 30 \text { yo) } \\
\text { who is stateless } \\
\text { and has two } \\
\text { stateless children. }\end{array}$ & $\begin{array}{l}\text { Mother's mother } \\
\text { is Indian descent } \\
\text { but Malaysian } \\
\text { citizenship. On } \\
\text { birth certificate, } \\
\text { no info about } \\
\text { father. Father } \\
\text { unknown }\end{array}$ & $\begin{array}{l}\text { Had issues since } \\
\text { birth certificate } \\
\text { stated citizenship } \\
\text { unknown. Mother's } \\
\text { birth certificate } \\
\text { clearly states } \\
\text { mother is citizen. }\end{array}$ & Indian. \\
\hline $15 \mathrm{~S}$ & $\begin{array}{l}63 \text { year old woman } \\
\text { who has } \\
\text { permanent } \\
\text { residence but no } \\
\text { citizenship. }\end{array}$ & $\begin{array}{l}\text { Mother is } \\
\text { Malaysian citizen } \\
\text { (Indian descent). } \\
\text { She has three } \\
\text { siblings who have } \\
\text { Malaysian } \\
\text { citizenship. }\end{array}$ & $\begin{array}{l}\text { Lost her birth } \\
\text { certificate and was } \\
\text { not able to get a } \\
\text { new one. }\end{array}$ & Indian. \\
\hline $16 \mathrm{~S}$ & $\begin{array}{l}33 \text { year old woman } \\
\text { who was not born } \\
\text { in a hospital and } \\
\text { not issued a birth } \\
\text { certificate at birth } \\
\text { (1985). }\end{array}$ & $\begin{array}{l}\text { Father is } \\
\text { Malaysian of } \\
\text { Indian descent } \\
\text { and mother who } \\
\text { was adopted and } \\
\text { did not possess a } \\
\text { birth certificate or } \\
\text { IC. }\end{array}$ & $\begin{array}{l}\text { Had no birth } \\
\text { certificate until } \\
2009 \text {. Could not get } \\
\text { one since her } \\
\text { mother did not have } \\
\text { any documents. } \\
\text { Four other siblings } \\
\text { have citizenship } \\
\text { despite having same } \\
\text { parents. }\end{array}$ & Indian. \\
\hline $17 \mathrm{~S}$ & $\begin{array}{l}\text { Adopted child who } \\
\text { had acquired birth } \\
\text { certificate from } \\
\text { doctor from clinic } \\
\text { (fraudulent } \\
\text { document). }\end{array}$ & $\begin{array}{l}\text { Chinese adopted } \\
\text { parents. } \\
\text { Biological mother } \\
\text { was Chinese and } \\
\text { not married. Not } \\
\text { sure what } \\
\text { biological father } \\
\text { was. }\end{array}$ & $\begin{array}{l}\text { Parents } \\
\text { unknowingly } \\
\text { acquired fraudulent } \\
\text { birth certificate } \\
\text { from clinic when } \\
\text { child was adopted. } \\
\text { When child tried to } \\
\text { get IC at } 12 \text {, birth } \\
\text { certificate was } \\
\text { seized. }\end{array}$ & Chinese. \\
\hline $18 \mathrm{~S}$ & $\begin{array}{l}\text { Child's birth } \\
\text { registered late } \\
\text { because marriage } \\
\text { registered late. }\end{array}$ & $\begin{array}{l}\text { Father is } \\
\text { Malaysian } \\
\text { (Chinese) and } \\
\text { mother is } \\
\text { Indonesian from } \\
\text { Bali. }\end{array}$ & $\begin{array}{l}\text { Mother has been } \\
\text { trying to register } \\
\text { the child for some } \\
\text { time but has been } \\
\text { waiting. }\end{array}$ & $\begin{array}{l}\text { Chinese- } \\
\text { Indonesian. }\end{array}$ \\
\hline
\end{tabular}

Table 3: Lawyers. Paralegals, NGO representatives and Academics Interviewed

\begin{tabular}{|c|c|c|c|}
\hline $\begin{array}{l}\text { Anonym } \\
\text { ous } \\
\text { Indicator }\end{array}$ & Profession & $\begin{array}{l}\text { Encounters with } \\
\text { stateless persons }\end{array}$ & Cases \\
\hline \multicolumn{4}{|c|}{ PARALEGALS } \\
\hline $1 \mathrm{PL}$ & $\begin{array}{l}\text { Day job is sales } \\
\text { person but } \\
\text { volunteers with } \\
\text { local political } \\
\text { office to help } \\
\text { stateless } \\
\text { persons. }\end{array}$ & $\begin{array}{l}\text { Had worked in a MP's } \\
\text { office for a number of } \\
\text { years where } \\
\text { constituents came to } \\
\text { ask for help to get } \\
\text { citizenship. Has seen } 50 \\
\text { cases in } 9 \text { years with } \\
\text { only approximately } \\
20 \% \text { success rate. } \\
\text { Brought many stateless }\end{array}$ & $\begin{array}{l}\text { Case 1: Woman is } 7^{\text {th }} \text { child in a } \\
\text { family who wanted to get married } \\
\text { but could not because had no } \\
\text { documentation. After a lot of work } \\
\text { obtaining documentation for } \\
\text { hospital she was born in, she was } \\
\text { able to get identity documents. }\end{array}$ \\
\hline
\end{tabular}




\begin{tabular}{|c|c|c|c|}
\hline & & $\begin{array}{l}\text { persons to me to } \\
\text { interview. }\end{array}$ & \\
\hline $2 \mathrm{PL}$ & $\begin{array}{l}\text { Previously an } \\
\text { MP and now } \\
\text { runs social } \\
\text { services through } \\
\text { state funded } \\
\text { organisation. }\end{array}$ & $\begin{array}{l}\text { Assists persons in } \\
\text { catchment area in } \\
\text { citizenship applications } \\
\text { in Kuala Selangor. } \\
\text { Traveled to Sarawak to } \\
\text { assist } 150 \text { Iban people } \\
\text { to obtain identity cards. }\end{array}$ & \\
\hline \multicolumn{4}{|c|}{ LAWYERS } \\
\hline $1 \mathrm{~L}$ & $\begin{array}{l}\text { Public interest } \\
\text { lawyer for an } \\
\text { NGO. }\end{array}$ & $\begin{array}{l}\text { Stateless cases come } \\
\text { through community and } \\
\text { political referrals. }\end{array}$ & $\begin{array}{l}\text { Case 1: Thai woman married a } \\
\text { Malaysian man. At time of birth of } \\
\text { child, parents were not married. } \\
\text { Subsequently mother left. Applied } \\
\text { for citizenship but courts say } \\
\text { citizenship follows mother if } \\
\text { parents not married. At Federal } \\
\text { Court now. } \\
\text { Case 2: Three generations of } \\
\text { stateless persons: grandmother, } \\
\text { daughter and grandchildren. } \\
\text { Grandfather dead. Settled outside } \\
\text { of court after judge placed pressure } \\
\text { on Attorney General to. } \\
\text { Case 3: Parents are Malaysian } \\
\text { (Indian descent) but children were } \\
\text { born in India. Parents registered } \\
\text { children late at the Embassy of } \\
\text { Malaysia in India. The government } \\
\text { challenged issue of citizenship all } \\
\text { the way. } \\
\text { Case 4: Child was abandoned and } \\
\text { adopted by a family. Family } \\
\text { engaged in an unofficial adoption } \\
\text { and obtained fake papers. There } \\
\text { was no information as to where the } \\
\text { child came from. Adoption had to } \\
\text { be done properly but citizenship } \\
\text { not given in new birth certificate. } \\
\text { Going through courts now. } \\
\text { Case 5: Person born pre- } \\
\text { independence by parents who have } \\
\text { Malaysian citizenship but birth } \\
\text { was not registered. }\end{array}$ \\
\hline $2 \mathrm{~L}$ & $\begin{array}{l}\text { Family law } \\
\text { specialist that } \\
\text { had clients } \\
\text { seeking to adopt } \\
\text { stateless } \\
\text { persons. }\end{array}$ & $\begin{array}{l}\text { Clients asking for help } \\
\text { to adopt or resolve } \\
\text { citizenship issue. Also } \\
\text { gives summary advice. } \\
\text { In one case, had to } \\
\text { advise and advocate to } \\
\text { foreign embassies as to } \\
\text { why a child does not } \\
\text { have any } \\
\text { documentation and why } \\
\text { the child should still }\end{array}$ & $\begin{array}{l}\text { Case 1: Father was Malaysian and } \\
\text { mother Thai. They had a } \\
\text { customary marriage in Thailand } \\
\text { but it was not legal anywhere. } \\
\text { Mother disappeared and father } \\
\text { came to lawyer to obtain legal } \\
\text { rights over the child. Even though } \\
\text { child was biological, proceeded to } \\
\text { help father adopt child. When new } \\
\text { birth certificate issued, child was } \\
\text { stateless. Decision on birth }\end{array}$ \\
\hline
\end{tabular}




\begin{tabular}{|c|c|c|c|}
\hline & & travel with the family. & $\begin{array}{l}\text { certificate was going to be } \\
\text { challenged. Lost contact with } \\
\text { client after asked client to obtain } \\
\text { DNA evidence. } \\
\text { Case 2: Father was Malaysian and } \\
\text { mother was Chinese. Same } \\
\text { situation where helping parents } \\
\text { adopt child and trying to get new } \\
\text { birth certificate that would say } \\
\text { child is a citizen. } \\
\text { Case 3: Church approached } \\
\text { lawyer to help get Rohingya } \\
\text { stateless child to Germany to } \\
\text { obtain free medical treatment for a } \\
\text { severe respiratory problem. There } \\
\text { was no way of getting the baby to } \\
\text { travel because she had no access to } \\
\text { travel documents and UNHCR was } \\
\text { not issuing the documents to attest } \\
\text { the baby was a refugee. Baby } \\
\text { stayed in Malaysia and received } \\
\text { help with the Church. } \\
\text { Case } 4 \text { : Child born before parents } \\
\text { married. Father Malaysian (Indian } \\
\text { descent) and mother is Thai. } \\
\text { Helped with getting declaration of } \\
\text { legitimacy. Four year ordeal and } \\
\text { child may not be able to go to } \\
\text { school. Thai mother wants to go } \\
\text { back to Thailand but the child } \\
\text { doesn't want to. Marriage is on the } \\
\text { rocks. }\end{array}$ \\
\hline $3 \mathrm{~L}$ & $\begin{array}{l}\text { Lawyer that } \\
\text { does pro bono } \\
\text { statelessness } \\
\text { work. }\end{array}$ & $\begin{array}{l}\text { With law firm has done } \\
\text { about } 10 \text { pro bono cases } \\
\text { and given a lot of } \\
\text { summary advice. }\end{array}$ & $\begin{array}{l}\text { Have done cases involving Malay } \\
\text { Muslim, Chinese and Indian. Right } \\
\text { now all cases dealing with Chinese } \\
\text { who have married foreign women } \\
\text { from Indonesia, Thailand, } \\
\text { Cambodia and the Philippines. } \\
\text { Case 1: Parents unmarried. Father } \\
\text { Malaysian citizen (Indian descent) } \\
\text { and mother was Filipino and could } \\
\text { not be traced (not in child's life). } \\
\text { Originally had birth certificate said } \\
\text { citizen but when tried to get } \\
\text { passport, was issued another birth } \\
\text { certificate that said not citizen. } \\
\text { Application for citizenship denied } \\
\text { and was appealed. High Court } \\
\text { granted citizenship and appeal by } \\
\text { government rejected. } \\
\text { Case 2: Father is Malaysian } \\
\text { (Chinese descent) and mother is } \\
\text { Filipino. Case where parents not } \\
\text { married and despite DNA } \\
\text { evidence, during legitimacy }\end{array}$ \\
\hline
\end{tabular}




\begin{tabular}{|c|c|c|c|}
\hline & & & $\begin{array}{l}\text { proceedings judge commented that } \\
\text { father should adopt the child even } \\
\text { though child is biological child of } \\
\text { father. Case heading to the Federal } \\
\text { Court. } \\
\text { Case 3: Adopted child with } \\
\text { biological parents being father is } \\
\text { Malaysian citizen and mother } \\
\text { Indonesian. Case going through } \\
\text { courts. } \\
\text { Case 4: } 30 \text { year old man whose } \\
\text { father is Malaysian citizen (Indian } \\
\text { descent) and mother unknown. } \\
\text { There is no trace of the mother. } \\
\text { Father raised him but unable to } \\
\text { obtain citizenship despite DNA } \\
\text { evidence. }\end{array}$ \\
\hline $4 \mathrm{~L}$ & $\begin{array}{l}\text { Lawyer doing } \\
\text { work with an } \\
\text { NGO assisting } \\
\text { with stateless } \\
\text { persons. }\end{array}$ & $\begin{array}{l}\text { Mainly helped stateless } \\
\text { children through } \\
\text { adoption process. }\end{array}$ & $\begin{array}{l}\text { Case 1: Child was born before } \\
\text { parents were married (Father is } \\
\text { Malaysian citizen of Indian } \\
\text { descent and mother is Indonesian. } \\
\text { Applied for declaration of } \\
\text { legitimacy for child. Forced to } \\
\text { abandon relief of citizenship in } \\
\text { order to get legitimacy. Now } \\
\text { trying to obtain citizenship. } \\
\text { Case 2: Child born before parents } \\
\text { were married (Father is Malaysian } \\
\text { citizen of Indian descent and } \\
\text { mother is Papua New Guinean). } \\
\text { Not reported case. Legitimacy } \\
\text { granted but not citizenship. Relief } \\
\text { for citizenship withdrawn. Now } \\
\text { applying for citizenship through } \\
\text { registration office with declaration } \\
\text { of legitimacy. }\end{array}$ \\
\hline $5 \mathrm{~L}$ & $\begin{array}{l}\text { Lawyer who } \\
\text { was approached } \\
\text { by client with } \\
\text { personal } \\
\text { problem of } \\
\text { stateless child. }\end{array}$ & $\begin{array}{l}\text { Client came with } \\
\text { family problem. Gives } \\
\text { summary advice. Lot of } \\
\text { cases don't go forward } \\
\text { after giving advice. }\end{array}$ & $\begin{array}{l}\text { Case 1: Abandoned child that was } \\
\text { adopted by Malaysian parents of } \\
\text { Chinese descent. The clinic the } \\
\text { child was adopted from gave the } \\
\text { couple fake adoption papers } \\
\text { unbeknownst to the parents. When } \\
\text { the child applied for his identity } \\
\text { card at the age of 12, found out } \\
\text { stateless. The child's birth } \\
\text { certificate was deemed fraudulent } \\
\text { and issued new one stating child } \\
\text { not citizen. Child red flagged as } \\
\text { registration office noted that child } \\
\text { did not look Chinese. Decision on } \\
\text { birth certificate was judicially } \\
\text { reviewed successfully. This case } \\
\text { attracted attention of other people } \\
\text { and other clients came forward. } \\
\text { Case 2: Two cases involving two } \\
\text { siblings who are stateless. Adopted }\end{array}$ \\
\hline
\end{tabular}




\begin{tabular}{|c|c|c|c|}
\hline & & & $\begin{array}{l}\text { parents Chinese. Birth certificates } \\
\text { after adoption stated not citizens. } \\
\text { Judicially reviewed decision and } \\
\text { resolved. }\end{array}$ \\
\hline $6 \mathrm{~L}$ & $\begin{array}{l}\text { Lawyer who } \\
\text { works pro bono } \\
\text { with NGO on } \\
\text { stateless cases. }\end{array}$ & $\begin{array}{l}\text { Heard someone talking } \\
\text { about statelessness on a } \\
\text { panel and approached } \\
\text { NGO to help. NGO } \\
\text { focuses on helping } \\
\text { those of Indian descent } \\
\text { obtain citizenship. }\end{array}$ & $\begin{array}{l}\text { Case 1: Father is Malaysian } \\
\text { (Indian descent) and married an } \\
\text { Indonesian woman. Mother left } \\
\text { after child was born. Father was } \\
\text { biological child but had no legal } \\
\text { rights. Lawyer tried to have } \\
\text { grandmother adopt child but court } \\
\text { denied because it would } \\
\text { effectively made father and } \\
\text { daughter siblings on paper. } \\
\text { Proceeded to have father adopt the } \\
\text { child even with DNA evidence } \\
\text { indicating biological link. }\end{array}$ \\
\hline $7 \mathrm{~L}$ & $\begin{array}{l}\text { Lawyer that } \\
\text { worked at firm } \\
\text { previously that } \\
\text { represented } \\
\text { stateless } \\
\text { persons. }\end{array}$ & $\begin{array}{l}\text { Assisted senior } \\
\text { lawyers. }\end{array}$ & See $5 \mathrm{~L}$ for cases \\
\hline $8 \mathrm{~L}$ & $\begin{array}{l}\text { Lawyer working } \\
\text { with NGO on } \\
\text { stateless issues. }\end{array}$ & $\begin{array}{l}\text { Has given a lot of } \\
\text { summary advice to } \\
\text { stateless persons and } \\
\text { also represented some } \\
\text { through courts. } \\
\text { Advocating politically } \\
\text { for stateless persons } \\
\text { after learning from a } \\
\text { political party of } \\
\text { constituents asking for } \\
\text { help. }\end{array}$ & $\begin{array}{l}\text { Case 1: adopted child whose } \\
\text { father is Malaysian (Chinese) } \\
\text { descent and Thai mother. Going } \\
\text { through courts now. }\end{array}$ \\
\hline \multicolumn{4}{|c|}{ ACADEMICS AND RESEARCHERS } \\
\hline $1 \mathrm{~A}$ & $\begin{array}{l}\text { Academic who } \\
\text { researches on } \\
\text { international } \\
\text { law. }\end{array}$ & $\begin{array}{l}\text { Touches upon } \\
\text { citizenship issues } \\
\text { tangentially. }\end{array}$ & $\begin{array}{l}\text { Citizenship is a politically } \\
\text { sensitive issue. }\end{array}$ \\
\hline $2 \mathrm{~A}$ & $\begin{array}{l}\text { Academic who } \\
\text { works with } \\
\text { NGOs on } \\
\text { stateless issues. }\end{array}$ & Need to transcribe. & $\begin{array}{l}\text { Case 1: Spoke with Ambassador } \\
\text { of the Philippines about a stateless } \\
\text { woman who was a waitress who } \\
\text { had no documents. She was born } \\
\text { in Malaysia and spoke no Tagalog. } \\
\text { Was able to assist her in getting } \\
\text { passport but issue with traveling } \\
\text { because confusion as to why she } \\
\text { did not have an entry stamp into } \\
\text { Malaysia. }\end{array}$ \\
\hline 1PHD & PhD student. & $\begin{array}{l}\text { Dissertation on stateless } \\
\text { persons in Malaysia. }\end{array}$ & $\begin{array}{l}\text { Interviewed } 100 \text { stateless persons } \\
\text { mainly in Sabah. Confirmed many } \\
\text { cases arise out of persons not } \\
\text { registering births, marriages or } \\
\text { having appropriate documentation. }\end{array}$ \\
\hline \multicolumn{4}{|l|}{ NGOS } \\
\hline $1 \mathrm{NGO}$ & $\begin{array}{l}\text { International } \\
\text { NGO. }\end{array}$ & $\begin{array}{l}\text { Works predominantly } \\
\text { on refugee issues and } \\
\text { intersects with stateless } \\
\text { refugees. }\end{array}$ & $\begin{array}{l}\text { Case 1: Malaysian father and } \\
\text { Papua New Guinean mother - see } \\
\text { 4L. } \\
\text { Engaged in mapping project of }\end{array}$ \\
\hline
\end{tabular}




\begin{tabular}{|c|c|c|c|}
\hline & & & $\begin{array}{l}\text { stateless persons of Indian descent } \\
\text { in Malaysia. Identified following } \\
\text { as stateless: } \\
\text { - } \quad \text { Those working at } \\
\text { plantations before } \\
\text { Malaysian independence } \\
\text { (mostly of Indian descent) } \\
\text { - } \quad \text { Baja Laut (nomadic } \\
\text { population) } \\
\text { - } \quad \text { Filipino refugees } \\
\text { - Migrant workers from the } \\
\quad \text { Philippines and Indonesia } \\
\text { - } \quad \text { Indigenous people } \\
\end{array}$ \\
\hline $2 \mathrm{NGO}$ & $\begin{array}{l}\text { NGO that helps } \\
\text { street kids. }\end{array}$ & $\begin{array}{l}\text { Helping out kids and } \\
\text { discovering they are } \\
\text { stateless. Discovered } \\
\text { there is a market for } \\
\text { babies. Founder of } \\
\text { NGO adopted a } \\
\text { stateless child that } \\
\text { could not be sold to } \\
\text { anyone. }\end{array}$ & $\begin{array}{l}\text { Case 1: Founder's child is an } \\
\text { abandoned stateless baby that was } \\
\text { sold to her. Daughter is } 10 \text { years } \\
\text { old and still stateless today. } \\
\text { Case 2: Two stateless kids with } \\
\text { Malaysian father and Indonesian } \\
\text { mother. Children were adopted. } \\
\text { Biological father in prison and } \\
\text { mother is untraceable. Adopted } \\
\text { mother could not handle kids and } \\
\text { abandoned them. A US couple } \\
\text { wanted to adopt but was prevented } \\
\text { because only Muslims can adopt } \\
\text { Muslim children. US couple } \\
\text { converted. When applying for } \\
\text { adoption, court denied to foreign } \\
\text { couple on basis that fear that } \\
\text { couple would just convert back to } \\
\text { Christianity. US adoption was } \\
\text { denied as well. Children now } \\
\text { entering early teens. }\end{array}$ \\
\hline $3 \mathrm{NGO}$ & $\begin{array}{l}\text { Former } \\
\text { employee of a } \\
\text { network of } \\
\text { NGOs. }\end{array}$ & $\begin{array}{l}\text { NGOs in network } \\
\text { working with stateless. }\end{array}$ & $\begin{array}{l}\text { Case 1: } 70 \text { year old man in } \\
\text { detention. See } 7 \text { NGO } \\
\text { Case 2: Aware of cases of stateless } \\
\text { persons of Filipino descent } \\
\text { deported to the Philippines even } \\
\text { though never set foot there. People } \\
\text { agree to getting deported because } \\
\text { better than staying in detention. } \\
\text { Some come back to Malaysia. }\end{array}$ \\
\hline 4NGO & $\begin{array}{l}\text { Representative } \\
\text { of international } \\
\text { organization. }\end{array}$ & $\begin{array}{l}\text { Works predominantly } \\
\text { with refugees. }\end{array}$ & $\begin{array}{l}\text { Aware of stateless persons in } \\
\text { detention. People get picked up } \\
\text { because don't have identification. } \\
\text { Not everyone gets refugee } \\
\text { document from UNHCR and that } \\
\text { problem creates limbo and grey } \\
\text { zones for people. }\end{array}$ \\
\hline $5 \mathrm{NGO}$ & $\begin{array}{l}\text { International } \\
\text { organization } \\
\text { that works on } \\
\text { statelessness. } \\
\end{array}$ & $\begin{array}{l}\text { Experience working } \\
\text { with stateless persons. }\end{array}$ & Confirmed 4NGO information. \\
\hline 6NGO & $\begin{array}{l}\text { Lawyer who } \\
\text { started an NGO } \\
\text { that is an } \\
\text { umbrella group }\end{array}$ & $\begin{array}{l}\text { Engages in out of court } \\
\text { advocacy work for } \\
\text { stateless children. } \\
\text { Refers cases to lawyers. }\end{array}$ & $\begin{array}{l}\text { Case 1: Child born when parents } \\
\text { were not married. Parents married } \\
\text { for } 10 \text { years now and child is now } \\
\text { 12. Father Malaysian (Chinese }\end{array}$ \\
\hline
\end{tabular}




\begin{tabular}{|c|c|c|c|}
\hline & $\begin{array}{l}\text { of children's } \\
\text { organizations. }\end{array}$ & & 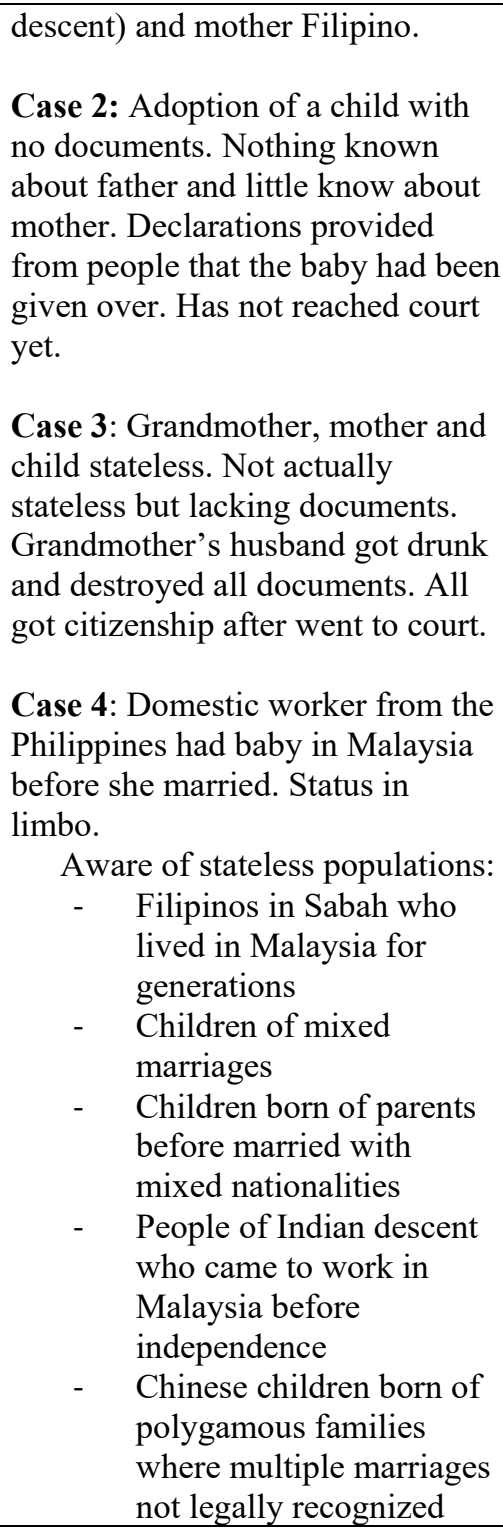 \\
\hline $7 \mathrm{NGO}$ & $\begin{array}{l}\text { Civil society } \\
\text { network } \\
\text { engaged in } \\
\text { advocacy, } \\
\text { capacity } \\
\text { building, } \\
\text { research and } \\
\text { awareness } \\
\text { raising on a } \\
\text { number of } \\
\text { issues. }\end{array}$ & $\begin{array}{l}\text { Focused on } \\
\text { immigration detention } \\
\text { and encountered } \\
\text { stateless persons in } \\
\text { detention or through } \\
\text { work with organization } \\
\text { in network. }\end{array}$ & $\begin{array}{l}\text { Case 1: Boy abandoned by parents } \\
\text { at Thai-Malaysia border. Grew up } \\
\text { in Malaysia and was detained at } 14 \\
\text { for two years, part of the time in } \\
\text { solitary confinement. Not able to } \\
\text { track down parents. Was just } \\
\text { picked up on a random check. } \\
\text { Unsure if still in detention. } \\
\text { Case 2: } 70 \text { year old Chinese man } \\
\text { detained. Had no documents and } \\
\text { not in government system despite } \\
\text { saying he was born in Malaysia. } \\
\text { Placed a newspaper ad trying to } \\
\text { find someone to identify the man } \\
\text { but no one came forward. }\end{array}$ \\
\hline $8 \mathrm{NGO}$ & $\begin{array}{l}\text { NGO deals with } \\
\text { abandoned } \\
\text { children. }\end{array}$ & $\begin{array}{l}\text { Operates a baby hatch } \\
\text { for abandoned children } \\
\text { who are undocumented } \\
\text { and therefore stateless. }\end{array}$ & $\begin{array}{l}\text { For abandoned babies, when } \\
\text { registering birth, their birth } \\
\text { certificate defaults to not a citizen. }\end{array}$ \\
\hline
\end{tabular}




\begin{tabular}{|c|c|c|c|}
\hline & & & $\begin{array}{l}\text { of a domestic worker from the } \\
\text { Philippines. Malaysia did not give } \\
\text { citizenship but were able to give } \\
\text { citizenship from her own country } \\
\text { in Europe. } \\
\text { Aware of many cases of baby } \\
\text { abandonment for reasons: } \\
\text { - Foreign workers having } \\
\text { children while in } \\
\text { Malaysia } \\
\text { - Women having children } \\
\text { - } \quad \text { Wout of wedlock } \\
\text { raise a child } \\
\text { - Children rescued from } \\
\text { baby selling rackets }\end{array}$ \\
\hline $9 \mathrm{NGO}$ & $\begin{array}{l}\text { Network of } \\
\text { many Muslim } \\
\text { organizations } \\
\text { that works on } \\
\text { development, } \\
\text { social and } \\
\text { economic } \\
\text { issues. }\end{array}$ & $\begin{array}{l}\text { Works with refugees } \\
\text { and migrants. }\end{array}$ & \\
\hline $10 \mathrm{NGO}$ & $\begin{array}{l}\text { Founder of } \\
\text { NGO that helps } \\
\text { street children. }\end{array}$ & $\begin{array}{l}\text { Encountered stateless } \\
\text { children among } \\
\text { children NGO services } \\
\text { and adopted an } \\
\text { abandoned baby that } \\
\text { was being sold in the } \\
\text { black market. }\end{array}$ & $\begin{array}{l}\text { Case 1: Children adopted are } \\
\text { stateless and still trying to get } \\
\text { citizenship for them after many } \\
\text { years. }\end{array}$ \\
\hline $11 \mathrm{NGO}$ & $\begin{array}{l}\text { NGO that } \\
\text { provides legal } \\
\text { services to } \\
\text { refugees, and } \\
\text { community and } \\
\text { empowerment } \\
\text { programs. }\end{array}$ & $\begin{array}{l}\text { Encountered through } \\
\text { providing services for } \\
\text { Rohingya refugees. } \\
\text { Commented that } \\
\text { UNHCR and } \\
\text { government treats } \\
\text { refugees as using } \\
\text { Malaysia as a transit } \\
\text { point to other } \\
\text { resettlement locations } \\
\text { but that many don't see } \\
\text { Malaysia as transit but } \\
\text { final destination. }\end{array}$ & $\begin{array}{l}\text { Case 1: Rohingya woman in } \\
\text { Malaysia since 1986. No hope of } \\
\text { her getting citizenship. Lived in } \\
\text { Malaysia since she was five years } \\
\text { old. } \\
\text { Spoke in general about how } \\
\text { Rohingya don't even realise } \\
\text { stateless and are just trying to } \\
\text { survive. }\end{array}$ \\
\hline $12 \mathrm{NGO}$ & $\begin{array}{l}\text { NGO that } \\
\text { provides } \\
\text { services to } \\
\text { Indian Tamil } \\
\text { community. }\end{array}$ & $\begin{array}{l}\text { Encountered by } \\
\text { providing services to } \\
\text { community. }\end{array}$ & $\begin{array}{l}\text { Mapping of Indian Tamils who are } \\
\text { stateless and helping to register } \\
\text { them. }\end{array}$ \\
\hline $13 \mathrm{NGO}$ & $\begin{array}{l}\text { NGO that } \\
\text { provides } \\
\text { services to } \\
\text { remote locations } \\
\text { in Sabah. }\end{array}$ & $\begin{array}{l}\text { Encountered in helping } \\
\text { persons in Sabah. }\end{array}$ & $\begin{array}{l}\text { Providing paralegal assistance to } \\
\text { stateless in Sabah. }\end{array}$ \\
\hline
\end{tabular}

